\title{
Total Synthesis of Streptonigrone
}

\author{
Bryan K. Chan, Marco A. Ciufolini* \\ Department of Chemistry, University of British Columbia, 2036 Main Mall, Vancouver, BC V6T 1Z1, Canada
}

Supporting Information 
Table of Contents

$\begin{array}{lr}\text { Experimental Protocols } & \text { S3 }\end{array}$

Synthesis and Characterization of Various Intermediates S3

3,4-Dimethoxysalicylaldehyde, $28 \quad$ S3

2-Benzyloxy-3,4-dimethoxybenzaldehyde, $10 \quad$ S3

1,2,4-Trimethoxy-5-nitrobenzene S3

2,4,5-Trimethoxyaniline, $13 \quad$ S4

Tetrahydroquinoline $17 \quad$ S4

Quinolinoquinone $18 \quad$ S4

Methyl quinaldate $\quad$ S4

Ketoester 19

Nitroketone $20 \quad$ S5

Ketoester 23

Indolizine 21

Nitroindolizine $22 \quad$ S6

Indolizine $24 \quad 56$

Coumarin $33 \quad 56$

2-Cyanopropionamide, $34 \quad 56$

2-Acetylquinoline $\quad S 7$

$\begin{array}{ll}\text { Enone } 36 & \text { S7 }\end{array}$

$\begin{array}{ll}\text { Pyridone } 37 & \text { S7 }\end{array}$

$\begin{array}{ll}\text { lodopyridone } \mathbf{3 8} & \mathrm{S7}\end{array}$

$\begin{array}{ll}\text { lodopyridine } 39 & \text { S8 }\end{array}$

Table of Measured vs. Reported 1H Chemical Shifts for 1

$\begin{array}{cc}\text { Proton- and }{ }^{13} \text { C NMR spectra } & \\ \text { compound 14 } & \mathrm{S} 9 \\ \text { compound 15 } & \mathrm{S} 10 \\ \text { compound 16 } & \mathrm{S} 11 \\ \text { compound 12 } & \mathrm{S} 12 \\ \text { compound 40 } & \mathrm{S} 13 \\ \text { compound 41 } & \mathrm{S} 14 \\ \text { compound 42 } & \mathrm{S} 15 \\ \text { compound 44 } & \mathrm{S} 16 \\ \text { compound 46 } & \mathrm{S} 17 \\ \text { compound 47 } & \mathrm{S} 18 \\ \text { compound 50 } & \mathrm{S} 19 \\ \text { streptonigrone 1 } & \mathrm{S} 20 \\ \text { compound 28 } & \mathrm{S} 24 \\ \text { compound 10 } & \mathrm{S} 25 \\ \text { 2,4,5-trimethoxynitrobenzene } & \mathrm{S} 26 \\ \text { compound 13 } & \mathrm{S} 27 \\ \text { compound 17 } & \mathrm{S} 28 \\ \text { compound 18 } & \mathrm{S} 28 \\ \text { compound 19 } & \mathrm{S} 29 \\ \text { compound 20 } & \mathrm{S} 30 \\ \text { compound 21 } & \mathrm{S} 31 \\ \text { compound 22 } & \mathrm{S} 32 \\ \text { compound 23 } & \mathrm{S} 33 \\ \text { compound 24 } & \mathrm{S} 34 \\ \text { compound 33 } & \mathrm{S} 39 \\ \text { compound 34 } & \mathrm{S} 41 \\ \text { 2-acetylquinoline } & \mathrm{S} 42 \\ \text { compound 36 } & \mathrm{S} 43 \\ \text { compound 37 } & \mathrm{S} 44 \\ \text { compound 38 } & \mathrm{S} 45 \\ \text { compound 39 } & \mathrm{S} 46\end{array}$


Experimental Protocols. Unless otherwise stated, ${ }^{1} \mathrm{H}$ and ${ }^{13} \mathrm{C}$ NMR spectra were obtained from $\mathrm{CDCl}_{3}$ solutions. Chemical shifts are reported in parts per million (ppm) on the $\delta$ scale and coupling constants, $J$, are in hertz (Hz). Multiplicities are reported as "s" (singlet), "d" (doublet), “t” (triplet), “q” (quartet), “dd” (doublet of doublets), "td” (triplet of doublets), "m” (multiplet), “c” (complex), "br” (broad). FT-IR spectra $\left(\mathrm{cm}^{-1}\right)$ were from thin films deposited on $\mathrm{NaCl}$ plates. Low- and high-resolution mass spectra $(\mathrm{m} / \mathrm{z})$ were obtained in the electrospray (ESI) mode. Melting points are uncorrected. All reagents and solvents were commercial products and used without further purification except THF (freshly distilled from $\mathrm{Na}$ /benzophenone under $\mathrm{Ar}$ ) and $\mathrm{CH}_{2} \mathrm{Cl}_{2}$ (freshly distilled from $\mathrm{CaH}_{2}$ under Ar). Commercial $n$-BuLi was titrated against $N$-benzylbenzamide in THF at $-78^{\circ} \mathrm{C}$ until persistence of a light blue color. Flash chromatography was performed on Silicycle $230-400$ mesh silica gel. All reactions were performed under argon atmosphere in flame- or oven dried flasks equipped with Teflon ${ }^{\mathrm{TM}}$ stirbars. All flasks were fitted with rubber septa for the introduction of substrates, reagents, and solvents via syringe.

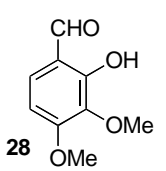

Aldehyde 28. A mixture of commercial 2,3,4-trimethoxybenzaldehyde (10.0 g, $51.2 \mathrm{mmol})$ and anhydrous $\mathrm{AlCl}_{3}(6.90 \mathrm{~g}, 51.7 \mathrm{mmol})$ in $\mathrm{PhH}(130 \mathrm{~mL}$; CAUTION: cancer suspect agent) was stirred at RT for 5 min, then it was heated at $75{ }^{\circ} \mathrm{C}$ for $5 \mathrm{~h}$. The mixture was then cooled to RT and quenched with water $(50 \mathrm{~mL})$ and conc. aq. $\mathrm{HCl}(20 \mathrm{~mL})$. The organic layer was separated and the aqueous layer was extracted with $\mathrm{Et}_{2} \mathrm{O}(4 \times 50 \mathrm{~mL})$. The combined organic extracts were washed with brine ( $2 \times 50 \mathrm{~mL})$, dried $\left(\mathrm{Na}_{2} \mathrm{SO}_{4}\right)$ and concentrated to give 28 (9.14 g, $\left.98.0 \%\right)$, off-white solid, m.p. 69.5-70.0 ${ }^{\circ} \mathrm{C}$ (lit. 70-72 ${ }^{\circ} \mathrm{C}$ : Reichstein, T.; Oppenauer, R.; Grussner, A.; Rhyner, L.; Glatthaar, C. Helv. Chim. Acta. 1935, 18, 816). ${ }^{1} \mathbf{H}: 11.20$ (s, 1H), 9.75 (s, 1H), 7.29 (d, 2H, $J=8.72$ ), 6.61 (d, $2 \mathrm{H}, J=8.72$ ), 3.95 (s, 3H), 3.91 (s, 3H). ${ }^{13} \mathrm{C}: 195.1,159.5$, 155.9, 136.3, 130.4, 116.7, 104.2, 60.9, 56.4. IR: 2939, 1642, 1505. ESI-MS: $183.3[\mathrm{M}+\mathrm{H}]^{+}$, $205.2[\mathrm{M}+\mathrm{Na}]^{+}$. HRMS calcd for $\mathrm{C}_{9} \mathrm{H}_{10} \mathrm{O}_{4}[\mathrm{M}+\mathrm{Na}]^{+}=205.0477$, found 205.0484

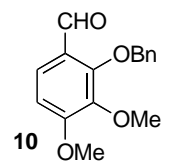

Aldehyde 10. A mixture of 28 (9.14 g, 50.45 mmol), $\mathrm{K}_{2} \mathrm{CO}_{3}(20 \mathrm{~g}, 151.4$ $\mathrm{mmol})$ and $\mathrm{BnBr}(6.08 \mathrm{~mL}, 51.2 \mathrm{mmol})$ in DMF $(150 \mathrm{~mL})$ was stirred at RT for $18 \mathrm{~h}$. The mixture was then quenched with water $(200 \mathrm{~mL})$ and extracted with $\mathrm{Et}_{2} \mathrm{O}(5 \times 100 \mathrm{~mL})$. The combined organic extracts were washed with brine $(3 \times 50 \mathrm{~mL})$, dried $\left(\mathrm{Na}_{2} \mathrm{SO}_{4}\right)$ and concentrated to give $10(13.4 \mathrm{~g}, 98 \%)$

as a yellow oil. ${ }^{1} \mathbf{H}$ : $10.09(\mathrm{~s}, 1 \mathrm{H}), 7.55(\mathrm{~d}, 1 \mathrm{H}, J=8.79), 7.25-7.39(\mathrm{~m}, 5 \mathrm{H}), 6.72$ (d, $1 \mathrm{H}, J=$ 8.77), 5.19 (s, 2H), 3.88 (s, 6H). ${ }^{13} \mathrm{C}: 188.8,159.4,155.6,142.0,136.6,128.73,128.72,128.6$, 124.1, 124.0, 107.9, 76.8, 61.1, 56.3. IR: 1679, 1590. ESI-MS: $295.1[\mathrm{M}+\mathrm{Na}]^{+}$. HRMS calcd for $\mathrm{C}_{16} \mathrm{H}_{16} \mathrm{O}_{4}[\mathrm{M}+\mathrm{Na}]^{+}=295.0946$, found 295.0952.

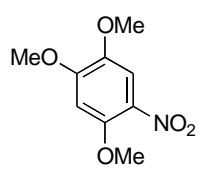

1,2,4-Trimethoxy-5-nitrobenzene. A solution of $70 \% \mathrm{HNO}_{3}(5 \mathrm{~mL})$ in AcOH $(20 \mathrm{~mL})$ was added dropwise to a solution of 1,2,4-trimethoxybenzene (16.3 g, $96.9 \mathrm{mmol})$ in AcOH $(120 \mathrm{~mL})$. The mixture was stirred at RT for 10 min, resulting in a yellow slurry that was carefully diluted with water (100 $\mathrm{mL})$. The yellow solid was filtered, washed with ice-water (3 x $100 \mathrm{~mL})$, and taken up in DCM $(200 \mathrm{~mL})$. The resulting solution was washed with sat. aq. $\mathrm{NaHCO}_{3}(2 \times 50$ $\mathrm{mL})$, dried $\left(\mathrm{Na}_{2} \mathrm{SO}_{4}\right)$ and concentrated. The residue was recrystallized $(\mathrm{MeOH})$ to afford the title compound $(13.0 \mathrm{~g}, 63 \%)$ as a yellow crystalline solid, m.p.124-126 ${ }^{\circ} \mathrm{C}$ (lit. $123-124{ }^{\circ} \mathrm{C}$ : Downer, N. K.; Jackson, A. J. Org. Biomol. Chem. 2004, 2, 3039). ${ }^{\mathbf{1}} \mathbf{H}: 7.56$ (s, 1H), 6.55 (s, 1H), 3.97 (s, 3H), 3.96 (s, 3H), 3.88 (s, 3H). ${ }^{13} \mathrm{C}: 155.8,151.4,143.4,131.9,110.0$, 98.6, 58.2, 57.52, 57.45. IR: 2950, 1519. ESI-MS: $236.2[\mathrm{M}+\mathrm{Na}]^{+}$. HRMS calcd for $\mathrm{C}_{9} \mathrm{H}_{11} \mathrm{NO}_{5}[\mathrm{M}+$ $\mathrm{Na}]^{+}=236.0535$, found 236.0532. 


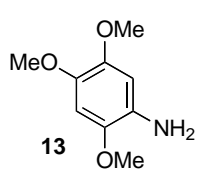

2,4,5-Trimethoxyaniline, 13. A suspension of the above nitro compound (5.13 g, $24.0 \mathrm{mmol})$ and 10\% Pd-C (300 mg, $280 \mathrm{mmol})$ in $\mathrm{MeOH}(225 \mathrm{~mL})$ was stirred under a $\mathrm{H}_{2}$ atmosphere at RT for $24 \mathrm{~h}$. The suspension was then filtered over Celite ${ }^{\circledR}$ and concentrated. The residue was dissolved in DCM $(150 \mathrm{~mL})$, washed with sat. aq. $\mathrm{NaHCO}_{3}(2$ x $50 \mathrm{~mL})$, dried $\left(\mathrm{Na}_{2} \mathrm{SO}_{4}\right)$ and concentrated to furnish the $\mathbf{1 3}$ (4.4 g, quant.) as a purple crystalline solid, m.p. 90-91 ${ }^{\circ} \mathrm{C}$ (lit.89.5-90.5 ${ }^{\circ} \mathrm{C}$ : Downer, N. K.; Jackson, A. J. Org. Biomol. Chem. 2004, 2, 3039). ${ }^{1} \mathbf{H}\left(\mathrm{MeOH}-\mathrm{d}_{4}\right): 6.62(\mathrm{~s}, 1 \mathrm{H}), 6.53(\mathrm{~s}, 1 \mathrm{H}), 3.81(\mathrm{~s}, 3 \mathrm{H}), 3.77(\mathrm{~s}, 3 \mathrm{H}), 3.75(\mathrm{~s}, 3 \mathrm{H}) .{ }^{13} \mathbf{C}$ $\left(\mathrm{MeOH}-\mathrm{d}_{4}\right):$ 145.5, 143.40, 143.37, 131.5, 104.5, 102.11, 58.3, 57.5, 57.1. IR: 3393, 1527. ESI-MS: $206.3[\mathrm{M}+\mathrm{Na}]^{+}$. HRMS calcd for $\mathrm{C}_{9} \mathrm{H}_{13} \mathrm{NO}_{3}[\mathrm{M}+\mathrm{Na}]^{+}=206.0793$, found 206.0791.

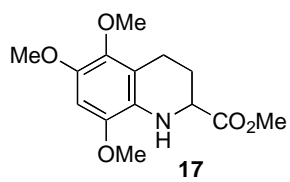

Tetrahydroquinoline 17. A mixture of 16 (60 mg, $0.193 \mathrm{mmol}), 10 \%$ Pd-C (20 mg, $0.019 \mathrm{mmol})$ in EtOH $(7 \mathrm{~mL})$ was stirred under an $\mathrm{H}_{2}$ atmosphere at RT for $45 \mathrm{~min}$, then it was filtered over Celite ${ }^{\circledR}$ and concentrated to afford pure $\mathbf{1 7}$ (50 $\mathrm{mg}, 96 \%)$ as a yellow paste. ${ }^{1} \mathbf{H}$ : 6.40 (s, $1 \mathrm{H}), 4.49$ (br. s, $1 \mathrm{H}), 4.0$ (m, 1H), 3.83 (s, 3H), 3.82 (s, 3H),

3.77 (s, 3H), 3.76 (s, 3H), 2.74-2.84 (m, 2H), 2.24-2.31 (m, 1H), 1.98-2.07 (m, 1H). ESI-MS: $282.1[\mathrm{M}+\mathrm{H}]^{+}$.

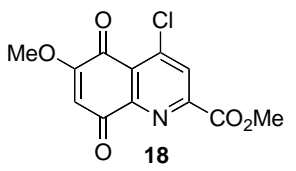

Quinolinoquinone 18. To a cold $\left(0{ }^{\circ} \mathrm{C}\right)$ solution of 16 (24 mg, 0.0769 mmol) in acetic anhydride $(2 \mathrm{~mL})$ was added $90 \%$ fuming $\mathrm{HNO}_{3}(0.1$ $\mathrm{mL}$ ). After $1 \mathrm{~h}$ of stirring at $0{ }^{\circ} \mathrm{C}$, the mixture was quenched with water $(10 \mathrm{~mL})$ and extracted with EtOAc $(3 \times 10 \mathrm{~mL})$. The combined organic extracts were washed with sat. aq. $\mathrm{NaHCO}_{3}(3 \times 10 \mathrm{~mL})$ and

brine (10 mL), dried $\left(\mathrm{Na}_{2} \mathrm{SO}_{4}\right)$ and concentrated. ${ }^{1} \mathbf{H}$ : $8.32(\mathrm{~s}, 1 \mathrm{H}), 6.26(\mathrm{~s}, 1 \mathrm{H}), 4.02(\mathrm{~s}, 3 \mathrm{H})$, $3.93(\mathrm{~s}, 3 \mathrm{H})$.

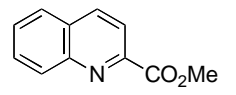

Methyl quinaldate. To a suspension of quinaldic acid (6.58 g, 38.0 $\mathrm{mmol})$ in $\mathrm{MeOH}(70 \mathrm{~mL})$ was added a $1.25 \mathrm{M} \mathrm{HCl}$ in methanol solution (70 mL). The resulting solution was refluxed for $15 \mathrm{~h}$. The mixture was then cooled to RT and concentrated in vacuo. The residue was partitioned between sat. aq. $\mathrm{NaHCO}_{3}(100 \mathrm{~mL})$ and EtOAc $(3 \times 75 \mathrm{~mL})$. The combined organic extracts were washed with sat. aq. $\mathrm{NaHCO}_{3}(25 \mathrm{~mL})$ and water $(25 \mathrm{~mL})$, dried $\left(\mathrm{Na}_{2} \mathrm{SO}_{4}\right)$, and concentrated in vacuo to give the desired ester (5.85 g, 82\%), white solid, m.p. $82-83{ }^{\circ} \mathrm{C}$ (lit. 81-83 ${ }^{\circ} \mathrm{C}$ : Weitgenant, J. A.; Mortison, J. D.; Helquist, P. Org. Lett. 2005, 7, 3609). ${ }^{1} \mathbf{H}: 8.30$ (d, 2H, J = 8.48), 8.19 (d, $1 \mathrm{H}, J=8.50$ ), 7.87 (d, $1 \mathrm{H}, J=8.27$ ), 7.78 (t, $1 \mathrm{H}, J=7.17$ ), 7.64 (t, $1 \mathrm{H}, J=7.40), 4.08$ (s, 3H). ${ }^{13} \mathrm{C}: 167.0,148.9,148.6,138.3,131.7,131.3,130.4,129.6,128.6,122.0,54.2$. IR: 1714. ESI-MS: $210.2[\mathrm{M}+\mathrm{Na}]^{+}$. HRMS calcd for $\mathrm{C}_{11} \mathrm{H}_{9} \mathrm{NO}_{2}[\mathrm{M}+\mathrm{Na}]^{+}=210.0531$, found 210.0536. EA: calcd C 70.58\%, H 4.85\%, N 7.48\%; found C 70.50\%, H 4.75\%, N 7.52\%.

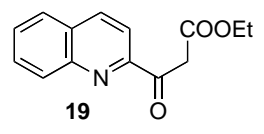

Ketoester 19. Solid t-BuOK (3.00 g, $26.7 \mathrm{mmol})$ was slowly added to a solution of methyl quinaldate (3.73 g, $19.9 \mathrm{mmol})$ in EtOAc $(75 \mathrm{~mL})$ at RT. The mixture was stirred for $15 \mathrm{~min}$ at RT, then it was quenched with water $(120 \mathrm{~mL})$. The organic layer was separated and the aqueous

phase was extracted with EtOAc $(3 \times 50 \mathrm{~mL})$. The combined organic extracts were washed with water $(50 \mathrm{~mL})$ and brine $(50 \mathrm{~mL})$, dried $\left(\mathrm{Na}_{2} \mathrm{SO}_{4}\right)$ and concentrated. Purification of the crude residue by flash chromatography (EtOAc : hexanes, 1:4) afforded 19 (5.91 g, 98\%) as an off-white paste. ${ }^{1} \mathbf{H}$ (major keto-tautomer): 8.24 (d, $\left.1 \mathrm{H}, J=8.50\right), 8.13(\mathrm{~m}, 2 \mathrm{H}$, overlapping resonance signals), 7.84 (d, $1 \mathrm{H}, J=8.17$ ), 7.75 (td, $1 \mathrm{H}, J=6.92, J=1.35$ ), 7.62 
(td, $1 \mathrm{H}, J=8.06, J=1.05), 4.34$ (s, 2H), 4.20 (q, $2 \mathrm{H}, J=7.13), 1.22$ (t, $3 \mathrm{H}, J=7.13) .{ }^{13} \mathrm{C}$ : 195.9, 169.4, 152.9, 148.0, 138.1, 131.5, 131.1, 130.7, 129.9, 128.7, 119.0, 62.1, 45.7, 15.1. IR: 1742, 1702. ESI-MS: $266.1[\mathrm{M}+\mathrm{Na}]^{+}, 509.1[2 \mathrm{M}+\mathrm{Na}]^{+}$. HRMS calcd for $\mathrm{C}_{14} \mathrm{H}_{13} \mathrm{NO}_{3}$ $[\mathrm{M}+\mathrm{Na}]^{+}=266.0793$, found 266.0798. EA: calcd C 69.12\%, H 5.39\%, N 5.76\%; found C $68.86 \%$, H 5.45\%, N 6.02\%.

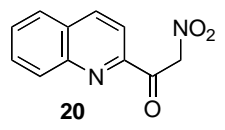

Nitroketone 20. 1,1'-Carbonyldiimidazole (7.08 g, $43.7 \mathrm{mmol})$ was slowly added to a solution of quinaldic acid (6.05 g, $34.94 \mathrm{mmol})$ in THF (70 mL) and stirred at RT for $30 \mathrm{~min}$ before the addition of $\mathrm{CH}_{3} \mathrm{NO}_{2}$ (11.3 mL, $\left.209.6 \mathrm{mmol}\right)$ and $\mathrm{KO}^{\mathrm{t}} \mathrm{Bu}(15.7 \mathrm{~g}, 140 \mathrm{mmol})$. The

mixture was stirred for $2 \mathrm{~h}$ at RT, then it was concentrated and partitioned betwen EtOAc $(100 \mathrm{~mL})$ and $0.1 \mathrm{M} \mathrm{HCl}(100 \mathrm{~mL})$. The organic layer was separated and the aqueous layer was extracted with EtOAc ( 2 x $50 \mathrm{~mL}$ ). The combined extracts were washed with brine (50 $\mathrm{mL}$ ), dried $\left(\mathrm{Na}_{2} \mathrm{SO}_{4}\right)$ and concentrated. Flash chromatrography (EtOAc : hexanes, 1:3) of the residue afforded $20(4.53 \mathrm{~g}, 61 \%)$ as a yellow solid. ${ }^{1} \mathbf{H}: 8.37$ (d, $\left.1 \mathrm{H}, J=8.59\right), 8.17(\mathrm{~d}, 1 \mathrm{H}, J$ = 8.50), 8.16 (d, $1 \mathrm{H}, J=8.81$ ), 7.93 (d, $1 \mathrm{H}, J=8.06$ ), 7.81-7.87 (m, 1H), 7.69-7.75 (m, $1 \mathrm{H})$, $6.62(\mathrm{~s}, 2 \mathrm{H})$.

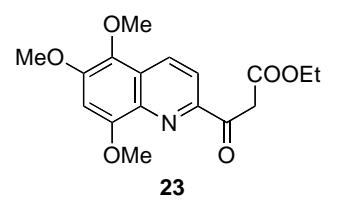

Ketoester 23. A suspension of 12 (1.05 g, $3.79 \mathrm{mmol})$ and $\mathrm{NaH}(60 \%$ dispersion, $0.50 \mathrm{~g}, 12.5 \mathrm{mmol})$ in EtOAc $(20 \mathrm{~mL})$ and toluene $(50 \mathrm{~mL})$ was stirred at $110{ }^{\circ} \mathrm{C}$ for $15 \mathrm{~h}$ (CAUTION: vigorous evolution of highly flammable $\mathrm{H}_{2}$ gas). The reaction was then cooled to RT and diluted with sat. aq. $\mathrm{NH}_{4} \mathrm{Cl}(100 \mathrm{~mL}$; CAUTION). The

aqueous phase was acidified to $\mathrm{pH} 4$ with $1 \mathrm{M} \mathrm{HCl}$ and extracted with EtOAc ( 3 x $50 \mathrm{~mL})$. The combined extracts were washed with brine $(50 \mathrm{~mL})$, dried $\left(\mathrm{Na}_{2} \mathrm{SO}_{4}\right)$ and concentrated in vacuo. Flash chromatography $\left(\mathrm{Et}_{2} \mathrm{O}\right.$ : hexanes, 1:2) of the residue afforded $27(0.830 \mathrm{~g}, 66 \%)$ as a yellow solid, m.p. 101.0-102.0 ${ }^{\circ} \mathrm{C} .{ }^{1} \mathbf{H}$ (major keto-tautomer): 8.49 (d, $1 \mathrm{H}, J=8.78$ ), 8.13 (d, $1 \mathrm{H}, J=8.78), 6.91$ (s, 1H), 4.38 (s, 2H), 4.22 (q, 2H, $J=7.14$ ), 4.11 (s, 3H), 4.07 (s, 3H), 3.93 (s, 3H), 1.26 (t, 3H, $J=7.13) .{ }^{13} \mathrm{C}: 195.8,169.6,154.7,152.0,149.9,136.3,135.1$, 131.7, 127.2, 119.8, 100.1, 62.5, 62.0, 57.9, 57.7, 45.6, 15.1. IR: 1743, 1688. ESI-MS: 334.1 $[\mathrm{M}+\mathrm{H}]^{+}$, $356.1[\mathrm{M}+\mathrm{Na}]^{+}$. HRMS calcd for $\mathrm{C}_{17} \mathrm{H}_{19} \mathrm{NO}_{6}[\mathrm{M}+\mathrm{Na}]^{+}=356.1110$, found 356.1100. EA: calcd C 61.25\%, H 5.75\%, N 4.20\%; found C 61.19\%, H 5.75\%, N 4.18\%.

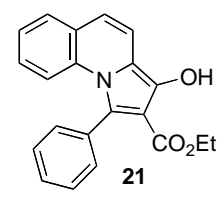

Indolizine 21. Piperidine (1.5 mL, $15.1 \mathrm{mmol})$ was added dropwise at RT to a solution of 19 (5.91 g, $24.3 \mathrm{mmol})$ and PhCHO (3.0 mL, $29.1 \mathrm{mmol})$ in EtOH $(12 \mathrm{~mL})$. The mixture was refluxed for $1 \mathrm{~h}$ and concentrated in vacuo. The residue was diluted with EtOAc $(100 \mathrm{~mL})$ and water $(50 \mathrm{~mL})$. The organic phase was separated and the aqueous layer was extracted with EtOAc ( $3 \times 50 \mathrm{~mL})$. The combined organic extracts were washed

with water $(2 \times 25 \mathrm{~mL})$, dried $\left(\mathrm{Na}_{2} \mathrm{SO}_{4}\right)$ and concentrated. The residue was purified by flash chromatography (EtOAc : hexane, 1:19) to afford $21(7.05 \mathrm{~g}, 87.5 \%)$ as a yellow solid, m.p. 114-116 ${ }^{\circ} \mathrm{C} .{ }^{1} \mathbf{H}: 8.30$ (s, $\left.1 \mathrm{H}\right), 7.41-7.52$ (m, 6H), 7.36 (d, $1 \mathrm{H}, J=9.31$ ), 7.17 (td, $1 \mathrm{H}, J=7.07$ $\mathrm{Hz}, J=1.02), 7.03$ (d, $1 \mathrm{H}, J=8.52), 6.93(\mathrm{~m}, 1 \mathrm{H}), 6.73$ (d, $1 \mathrm{H}, J=9.30), 4.11(\mathrm{q}, 2 \mathrm{H}, J=$ 7.21), 0.97 (t, 3H, $J=7.18) .{ }^{13} \mathrm{C}: 168.4,140.9,135.2,134.9,131.9,129.8,129.5,128.22$, 128.17, 127.5, 125.5, 118.9, 117.8, 117.2, 117.0, 105.7, 61.1, 14.7. IR: 3338, 1674. ESI-MS: $354.1[\mathrm{M}+\mathrm{Na}]^{+}$. HRMS calcd for $\mathrm{C}_{21} \mathrm{H}_{17} \mathrm{NO}_{3}[\mathrm{M}+\mathrm{Na}]^{+}=354.1106$, found 354.1107. EA: calcd C 76.12\%, H 5.17\%, N 4.23\%; found C 75.92\%, H 5.26\%, N 4.60\%. 


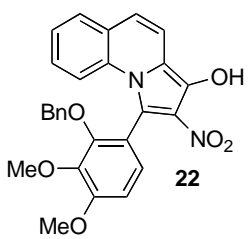

Nitroindolizine 22 A mixture of 20 (185 mg, $0.856 \mathrm{mmol}$ ), aldehyde 10 (256 mg, $0.942 \mathrm{mmol}$ ), $\mathrm{NH}_{4} \mathrm{OAc}$ (75 mg, $0.942 \mathrm{mmol}$ ) in toluene $(10 \mathrm{~mL})$ was refluxed for $3.5 \mathrm{~h}$. The reaction was then quenched with water $(10 \mathrm{~mL})$ and extracted with EtOAc $(3 \times 10 \mathrm{~mL})$. The combined organic extracts were washed with brine $(1 \times 10 \mathrm{~mL})$, dried $\left(\mathrm{Na}_{2} \mathrm{SO}_{4}\right)$ and concentrated. Flash chromatrography (EtOAc : hexanes, 1:5) of the residue afforded 22 (349 mg, 87\%) as a dark red paste. ${ }^{1} \mathbf{H}: 8.11(\mathrm{~s}, 1 \mathrm{H}), 7.47$ (d, $1 \mathrm{H}, J=$ 7.68), 7.33 (d, $1 \mathrm{H}, J=9.46$ ), 7.21 (d, $1 \mathrm{H}, J=7.85), 6.94-7.13$ (m, 6H), 6.74-6.88 (m, $4 \mathrm{H})$, 4.88 (s, 2H), 4.01 (s, 3H), 3.92 (s, 3H).

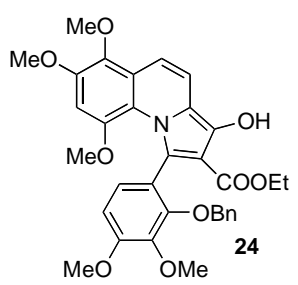

Indolizine 24. Piperidine $(0.010 \mathrm{~mL}, 0.101 \mathrm{mmol})$ was added dropwise to a solution of 27 (119 $\mathrm{mg}, 0.357 \mathrm{mmol}$ ) and 2-benzyloxy3,4-dimethoxybenzaldehyde (100 $\mathrm{mg}, 0.358 \mathrm{mmol})$ in ethanol (15 $\mathrm{mL})$. The mixture was refluxed for $35 \mathrm{~min}$, then it was diluted with water $(30 \mathrm{~mL})$ and EtOAc $(30 \mathrm{~mL})$. The organic layer was separated and the aqueous layer was extracted with more EtOAc $(3 \times 15 \mathrm{~mL})$. The combined extracts were washed with brine $(25 \mathrm{~mL})$, dried $\left(\mathrm{Na}_{2} \mathrm{SO}_{4}\right)$ and concentrated. Flash chromatography (EtOAc : hexane, 1:4) of the residue afforded the sensitive $\mathbf{2 8}$ (103 $\mathrm{mg}, 49.3 \%$ ) as a yellow paste. ${ }^{1} \mathbf{H}: 8.49$ (s, $1 \mathrm{H}), 7.34$ (d, $1 \mathrm{H}, J=9.45), 7.08-7.17(\mathrm{~m}, 4 \mathrm{H}), 6.98$ (d, $1 \mathrm{H}, J=9.45), 6.70-6.77$ (m, 3H), 6.26 (s, 1H), 4.52 (m, 2H, AB system), 4.03-4.23 (m, 2H), 3.92 (s, 3H), 3.84 (s, 3H), 3.795 (s, 3H), 3.790 (s, 3H), 3.09 (s, 3H), 1.12 (t, 3H, $J=7.12) .{ }^{13} \mathrm{C}: 168.3,154.0,151.1,150.5,147.4$, 143.0, 142.7, 138.3, 130.2, 128.9, 128.6, 128.3, 127.3, 126.0, 124.2, 118.8, 118.6, 118.4, 110.3, 107.3, 104.6, 96.3, 96.2, 75.4, 62.4, 61.9, 61.0, 57.3, 57.2, 55.2, 15.0. IR: 3254, 1666. ESI-MS: $610.1[\mathrm{M}+\mathrm{Na}]^{+}$. HRMS calcd for $\mathrm{C}_{33} \mathrm{H}_{33} \mathrm{NO}_{9}[\mathrm{M}+\mathrm{Na}]^{+}=610.2053$, found 610.2046 .

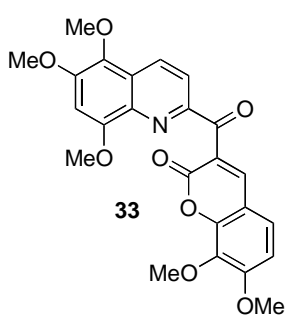

Coumarin 33. Piperidine ( 2 drops) was added to a solution of 27 (128 $\mathrm{mg}, 0.384 \mathrm{mmol}$ ) and 2-hydroxy-3,4-dimethoxybenzaldehyde (105 $\mathrm{mg}, 0.384 \mathrm{mmol})$ in $\mathrm{EtOH}(5 \mathrm{~mL})$, and the mixture was refluxed for 1 h. After cooling to RT, the mixture was diluted with water $(10 \mathrm{~mL})$ and extracted with EtOAc $(4 \times 10 \mathrm{~mL})$. The combined extracts were washed with brine $(10 \mathrm{~mL})$, dried $\left(\mathrm{Na}_{2} \mathrm{SO}_{4}\right)$ and concentrated. Flash chromatography (EtOAc : hexanes, 1:1) of the residue gave 35 (17 mg, $10 \%)$ as a yellow solid. ${ }^{1} \mathbf{H}$ : $8.54(\mathrm{~d}, 1 \mathrm{H}, J=8.76), 8.45(\mathrm{~s}, 1 \mathrm{H}), 8.13$

(d, $1 \mathrm{H}, J=8.77$ ), 7.35 (d, 1H, $J=8.71$ ), 6.94 (d, $1 \mathrm{H}, J=8.73$ ), $6.88(\mathrm{~s}, 1 \mathrm{H}), 4.04$ (s, 3H), 4.03 (s, 3H), 4.00 (s, 3H), 3.99 (s, 3H), 3.94 (s, 3H). ${ }^{13} \mathrm{C}: 191.1$, 158.1, 157.1, 153.7, 150.8, 150.3, 149.0, 147.6, 136.1, 135.5, 134.2, 130.9, 126.0, 124.9, 123.2, 120.1, 113.5, 108.9, 99.5, 61.55, 61.50, 57.0 (2 overlapping resonances), 56.5. IR: 1747, 1610. ESI-MS: $452.1[\mathrm{M}+\mathrm{H}]^{+}$, $474.1[\mathrm{M}+\mathrm{Na}]^{+}, 903.3[2 \mathrm{M}+\mathrm{H}]^{+}, 925.3[2 \mathrm{M}+\mathrm{Na}]^{+}$. HRMS calcd for $\mathrm{C}_{24} \mathrm{H}_{21} \mathrm{NO}_{8}[\mathrm{M}+$ $\mathrm{Na}]^{+}=474.1165$, found 474.1181 .

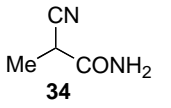

2-Cyanopropionamide, 34. Anhydrous $\mathrm{NH}_{3}$ gas (CAUTION: toxic and corrosive) was bubbled through a solution of 2-cyanopropanoic acid ethyl ester ( $4.00 \mathrm{~g}, 31.5 \mathrm{mmol})$ in ethanol $(30 \mathrm{~mL})$ for $20 \mathrm{~min}$. The solution was then stirred at RT for $15 \mathrm{~h}$ and concentrated to give 34 (3.00, 98\%) as an offwhite solid, m.p. 99.5-101.0 ${ }^{\circ} \mathrm{C} .{ }^{1} \mathbf{H}\left(\mathrm{MeOH}-\mathrm{d}_{4}\right)$ : 3.96 (q, $\left.1 \mathrm{H}, J=7.30\right), 1.52$ (d, 3H, $J=7.30$ ). ${ }^{13} \mathrm{C}: 170.6,119.7,32.8,16.1$. IR: 3360, 3192, 1668. HRMS calcd for $\mathrm{C}_{4} \mathrm{H}_{6} \mathrm{~N}_{2} \mathrm{O}[\mathrm{M}+\mathrm{H}]^{+}=$ 
99.0558, found 99.0560. EA: calcd C 48.97\%, H 6.16\%, N 28.56\%; found C 49.26\%, H $6.22 \%$, N 28.68\%.

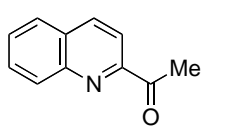

2-Acetylquinoline. A solution of 19 (1.75 g, $7.19 \mathrm{mmol})$ in 1,4-dioxane (20 $\mathrm{mL})$ containing aq. $1 \mathrm{M} \mathrm{HCl}(20 \mathrm{~mL})$ was stirred at $100{ }^{\circ} \mathrm{C}$ for $15 \mathrm{~h}$, then it was concentrated in vacuo. The residual aqueous phase was extracted with EtOAc ( 3 x $50 \mathrm{~mL}$ ). The combined extracts were washed with sat. $\mathrm{NaHCO}_{3}$ solution $(25 \mathrm{~mL})$ and brine $(25 \mathrm{~mL})$, dried $\left(\mathrm{Na}_{2} \mathrm{SO}_{4}\right)$ and evaporated. The residue was filtered through a bed of silica gel (hexanes : $\mathrm{CH}_{2} \mathrm{Cl}_{2}, 1: 4$ ) and concentrated to give 2-acetylquinoline (0.74 g, 60\%), white solid, m.p. $48-50.5{ }^{\circ} \mathrm{C}$ (lit. $53{ }^{\circ} \mathrm{C}$ : Capuano, L. Chem. Ber. 1959, 92, 2670). ${ }^{1} \mathbf{H}: 8.24$ (d, $\left.1 \mathrm{H}, J=8.54\right), 8.19$ (d, $1 \mathrm{H}, J=8.52$ ), 8.11 (d, $1 \mathrm{H}, J=8.51$ ), 7.85 (d, $1 \mathrm{H}, J$ = 8.10), 7.77 (td, $1 \mathrm{H}, J=6.93, J=1.30), 7.63(\mathrm{td}, 1 \mathrm{H}, J=7.93, J=0.92), 2.86(\mathrm{~s}, 3 \mathrm{H}) .{ }^{13} \mathrm{C}$ : 201.6, 154.2, 148.2, 137.8, 131.6, 130.9, 130.6, 129.5, 128.6, 118.9, 26.5. IR: 1697, 1359. HRMS calcd for $\mathrm{C}_{11} \mathrm{H}_{9} \mathrm{NO}[\mathrm{M}+\mathrm{Na}]^{+}=194.0582$, found 194.0576. EA: calcd C 77.17\%, $\mathrm{H}$ 5.30\%, N 8.18\%; found C 77.09\%, H 5.36\%, N 8.35\%.

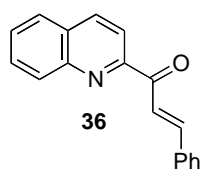

Enone 36. Water was added dropwise to a solution of 2-acetylquinoline (0.74 g, $4.3 \mathrm{mmol})$ in EtOH (40 mL) until the solution became slighly cloudy. Aqueous $10 \% \mathrm{NaOH}$ solution $(10 \mathrm{~mL})$ was then added dropwise and the mixture was stirred at RT for 5 min before the dropwise addition of PhCHO (0.30 mL, $4.34 \mathrm{mmol})$. An orange precipitate started to form. After

After stirring at RT for $2 \mathrm{~h}$, the solid was filtered and washed with ice-cold water $(10 \mathrm{~mL})$ to give 36 (0.93 g, 83\%), orange powder, m.p. $128.5-131.0{ }^{\circ} \mathrm{C} .{ }^{\mathbf{1}} \mathbf{H}: 8.55$ (d, $1 \mathrm{H}, J=16.1$ ), 8.18$8.40(\mathrm{~m}, 3 \mathrm{H}), 8.00(\mathrm{~d}, 1 \mathrm{H}, J=16.1), 7.57-7.93(\mathrm{~m}, 5 \mathrm{H}), 7.33-7.54(\mathrm{~m}, 3 \mathrm{H}){ }^{13} \mathrm{C}: 190.6,154.9$, 148.2, 145.6, 138.0, 136.3, 131.6, 131.5, 131.0, 130.5, 129.9 (overlapping resonance signals), 129.6, 128.7, 122.1, 120.1. IR: 1669, 1605, 1576, 1336. ESI-MS: $260.2[\mathrm{M}+\mathrm{H}]^{+}, 282.1[\mathrm{M}$ $+\mathrm{Na}]^{+}$. HRMS calcd for $\mathrm{C}_{18} \mathrm{H}_{13} \mathrm{NO}[\mathrm{M}+\mathrm{Na}]^{+}=282.0895$, found 282.0887. EA: calcd C 83.37\%, H 5.05\%, N 5.40\%; found C 83.35\%, H 5.14\%, N 5.53\%.

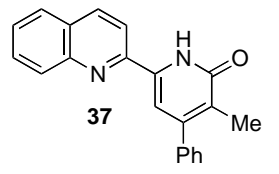

Pyridone 37. To a degassed solution of enone (100 $\mathrm{mg}, 0.386 \mathrm{mmol})$ and cyanopropanoic amide (42 $\mathrm{mg}, 0.425 \mathrm{mmol})$ in DMSO (2 mL) was added potassium tert-butoxide (90 $\mathrm{mg}, 0.780 \mathrm{mmol})$. The mixture was stirred at $95^{\circ} \mathrm{C}$ for $3.5 \mathrm{~h}$. After cooling to RT, the reaction was then quenched with $1 \mathrm{M} \mathrm{HCl}(15 \mathrm{~mL})$ and extracted with EtOAc $(4 \mathrm{x}$

$20 \mathrm{~mL})$. The combined organic extracts were washed with water $(2 \mathrm{x} 20 \mathrm{~mL})$ and brine $(2 \mathrm{x}$ $20 \mathrm{~mL}$ ), dried $\left(\mathrm{Na}_{2} \mathrm{SO}_{4}\right)$ and concentrated. Flash chromatrography (EtOAc : hexanes, 1:3) of the residue afforded 37 (120 mg, quant.) as a yellow solid, m.p. $210-21{ }^{\circ} \mathrm{C} .{ }^{\mathbf{1}} \mathbf{H}: 10.91$ (s, br, $1 \mathrm{H}), 8.22$ (d, $1 \mathrm{H}, J=8.68), 8.13(\mathrm{~d}, 1 \mathrm{H}, J=8.45), 7.82-7.85(\mathrm{~m}, 2 \mathrm{H}), 7.76-7.80(\mathrm{~m}, 1 \mathrm{H})$, 7.57-7.61 (m, 1H), 7.39-7.52 (m, 5H), 6.92 (s, 1H), 2.19 (s, 3H). ${ }^{13} \mathrm{C}: 164.4,151.3,148.6$, 148.2, 140.6, 138.7, 138.4, 131.5, 130.5, 130.0, 129.6, 129.24, 129.20, 129.0, 128.5, 117.4, 108.3, 15.2. IR: 3328, 3059, 1640, 1620, 1510. ESI-MS: $313.2[\mathrm{M}+\mathrm{H}]^{+}$. HRMS calcd for $\mathrm{C}_{21} \mathrm{H}_{16} \mathrm{~N}_{2} \mathrm{O}[\mathrm{M}+\mathrm{H}]^{+}=313.1341$, found 313.1336.

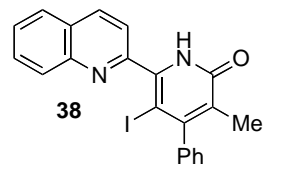

Iodopyridone 38. A mixture of 37 (20 $\mathrm{mg}, 0.0641 \mathrm{mmol})$ and potassium carbonate (60 mg, $0.454 \mathrm{mmol})$ in DMF $(1.5 \mathrm{~mL})$ was stirred at RT for $5 \mathrm{~min}$. Iodine monochloride (20 $\mathrm{mg}, 0.123 \mathrm{mmol}$ ) was then added and the resulting mixture was stirred in the dark at RT for $15 \mathrm{~h}$. The reaction was then diluted with sat. aq. $\mathrm{NH}_{4} \mathrm{Cl}(10 \mathrm{~mL})$ and extracted with EtOAc (4 x $10 \mathrm{~mL})$. The combined organic extracts were washed with sat. aq. $\mathrm{Na}_{2} \mathrm{~S}_{2} \mathrm{O}_{3}(10 \mathrm{~mL})$ and brine $(2 \mathrm{x} 10 \mathrm{~mL})$, dried $\left(\mathrm{Na}_{2} \mathrm{SO}_{4}\right)$ and concentrated. Flash 
chromatrography (EtOAc : hexanes, 1:3) of the residue afforded 38 (20 mg, 67\%) as an offwhite foamy solid. ${ }^{1} \mathbf{H}: 8.34$ (d, $\left.1 \mathrm{H}, J=8.63\right), 8.29$ (d, $\left.1 \mathrm{H}, J=8.66\right), 8.17$ (d, $1 \mathrm{H}, J=8.53$ ), 7.90 (d, $1 \mathrm{H}, J=8.11$ ), 7.82 (t, $1 \mathrm{H}, J=8.29$ ), 7.66 (t, $1 \mathrm{H}, J=8.06$ ), 7.42-7.53 (m, 3H), 7.14$7.18(\mathrm{~m}, 2 \mathrm{H}), 2.03$ (s, 3H). ESI-MS: $439.0[\mathrm{M}+\mathrm{H}]^{+}$.

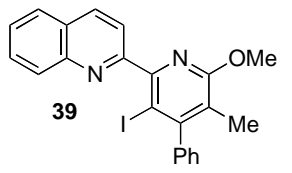

Iodopyridine 39. A suspension of 38 (8.0 mg, $0.018 \mathrm{mmol}), \mathrm{Ag}_{2} \mathrm{CO}_{3}$ (6.5 mg, $0.024 \mathrm{mmol})$ and $\mathrm{MeI}(0.010 \mathrm{~mL}, 0.16 \mathrm{mmol})$ was stirred in dark for $4 \mathrm{~d}$. The resulting mixture was filtered through a bed of Celite $^{\circledR}$ and concentrated to give $39(7.0 \mathrm{mg}, 85 \%)$ as a yellow paste. ${ }^{1} \mathrm{H}: 8.27$ (d, $\left.1 \mathrm{H}, J=8.5\right), 8.20$ (d, $\left.1 \mathrm{H}, J=8.5\right), 7.88$ (d, $1 \mathrm{H}, J=7.9$ ), 7.74-7.77 (m, 2H), 7.58 (t, 1H, J = 7.3), 7.39-7.51 (m, 3H), 7.14-7.18 (m, 2H), 4.00 (s, 3H), $2.03(\mathrm{~s}, 3 \mathrm{H})$. ESI-MS: $453.1[\mathrm{M}+\mathrm{H}]^{+}$.

Table 1: Measured vs. Reported ${ }^{1} \mathrm{H}$ Chemical Shifts for Synthetic and Natural 1. Note: the isolation paper (ref. 1 in the article) does not report ${ }^{13} \mathrm{C}$ data.

\begin{tabular}{|c|c|}
\hline Reported 1H Shifts (ppm) & Measured 1H Shifts (ppm) \\
\hline $8.36(\mathrm{ABq}, 2 \mathrm{H})$ & $8.37(\mathrm{ABq}, 2 \mathrm{H})$ \\
$6.84(\mathrm{~d}, 1 \mathrm{H}, J=9.0)$ & $6.83(\mathrm{~d}, 1 \mathrm{H}, J=8.6)$ \\
$6.66(\mathrm{~d}, 1 \mathrm{H}, J=9.0)$ & $6.65(\mathrm{~d}, 1 \mathrm{H}, J=8.6)$ \\
$6.34($ broad s, $1 \mathrm{H})$ & $6.31(\mathrm{broad} \mathrm{s}, 1 \mathrm{H})$ \\
$5.05($ broad s, 2H) & $5.04($ broad s, $2 \mathrm{H})$ \\
$4.06(\mathrm{~s}, 3 \mathrm{H})$ & $4.07(\mathrm{~s}, 3 \mathrm{H})$ \\
$3.99(\mathrm{~s}, 3 \mathrm{H})$ & $3.99(\mathrm{~s}, 3 \mathrm{H})$ \\
$3.95(\mathrm{~s}, 3 \mathrm{H})$ & $3.95(\mathrm{~s}, 3 \mathrm{H})$ \\
$2.03(\mathrm{~s}, 3 \mathrm{H})$ & $2.03(\mathrm{~s}, 3 \mathrm{H})$ \\
& \\
\hline
\end{tabular}


Chan and Ciufolini

Synthesis of Streptonigrone

Sq
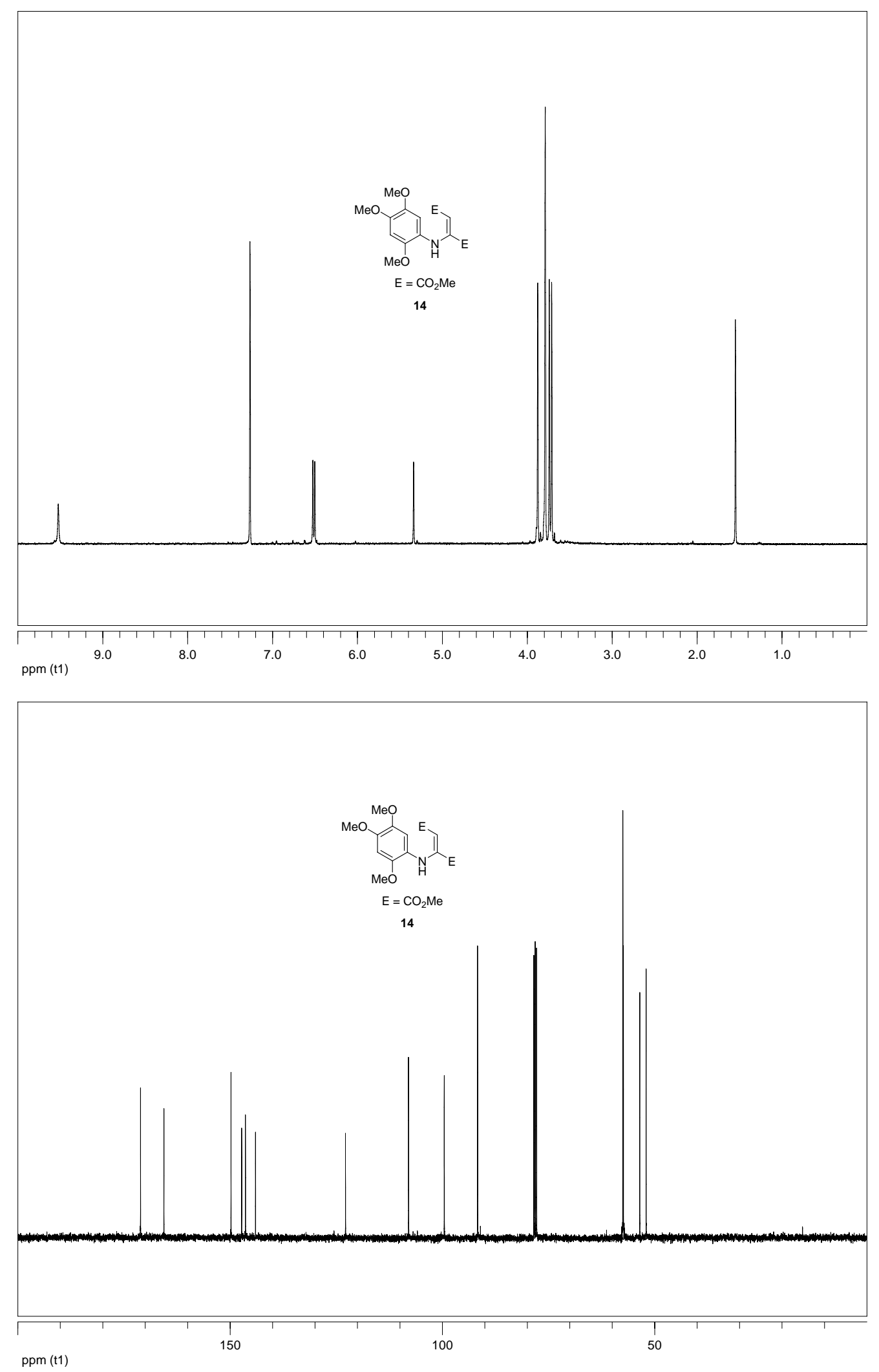


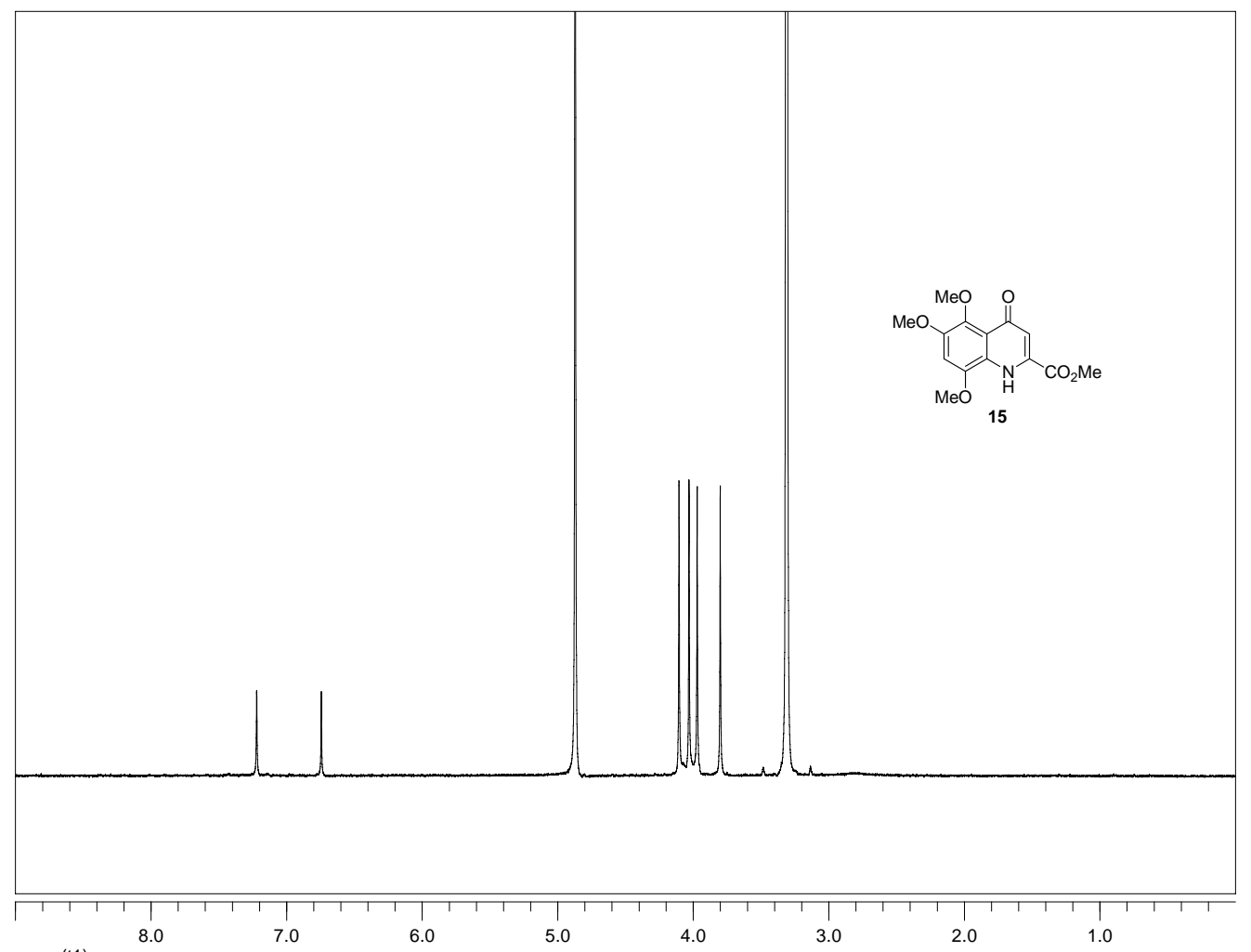

ppm (t1)

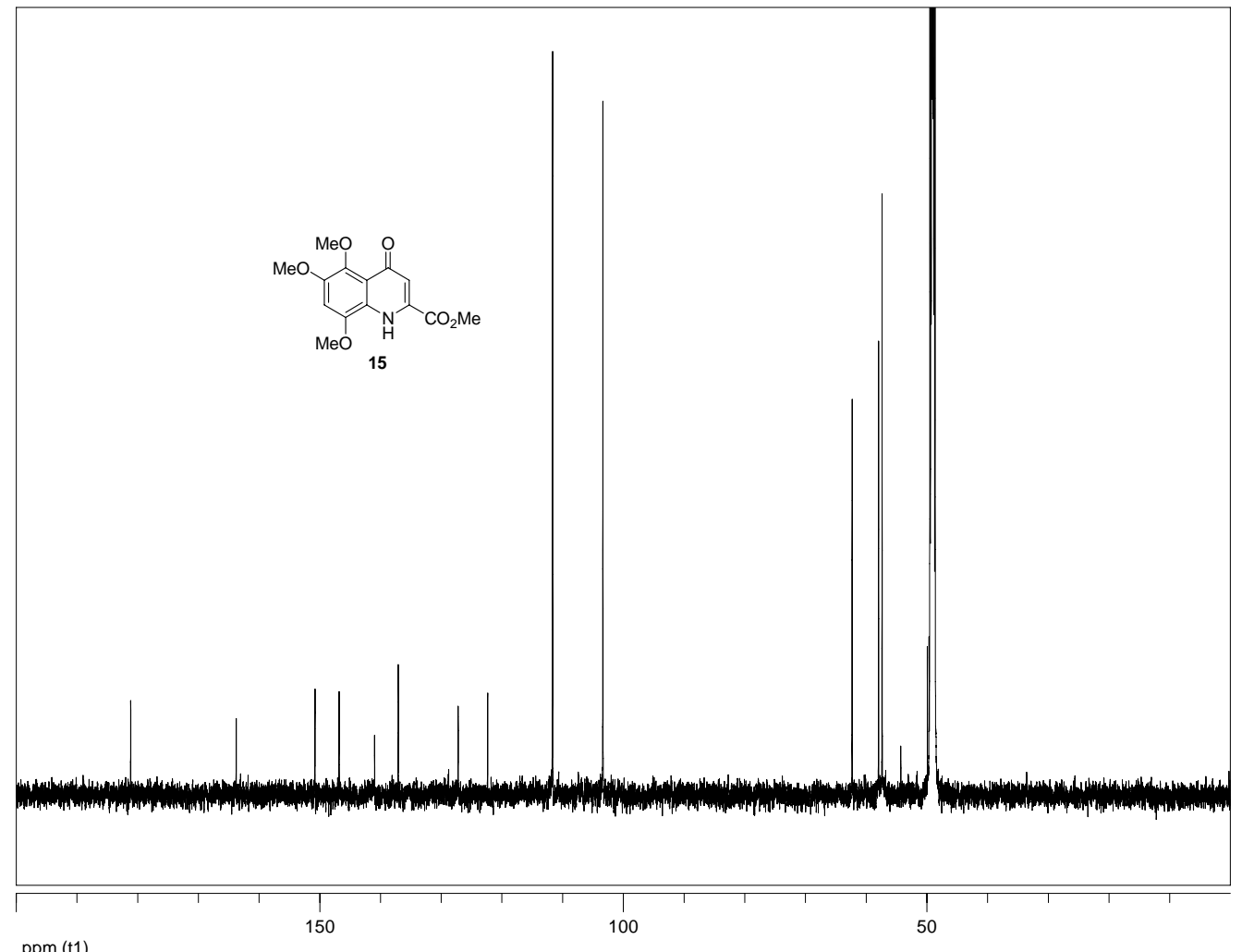

ppm (t1) 

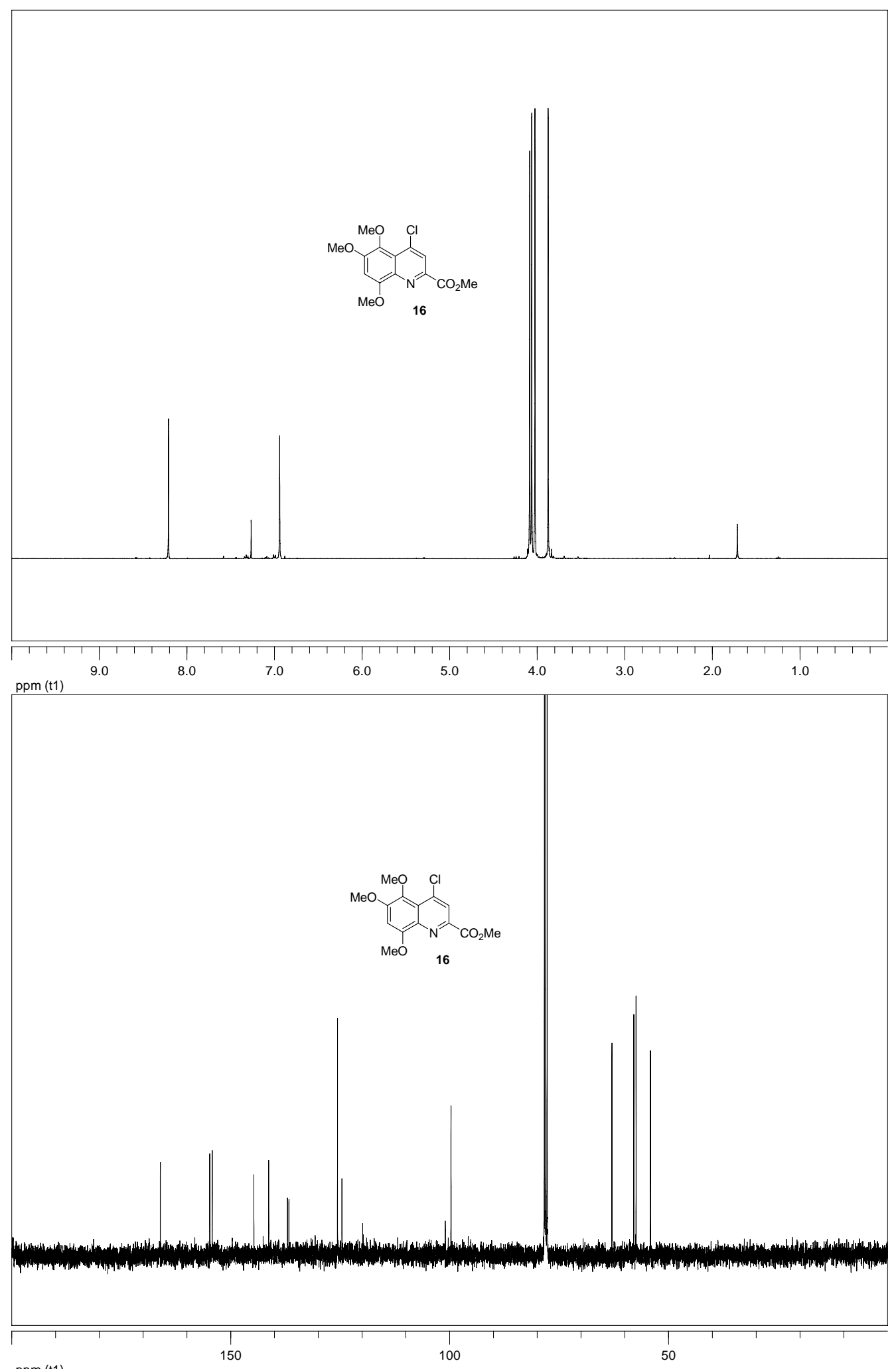

ppm (t1) 


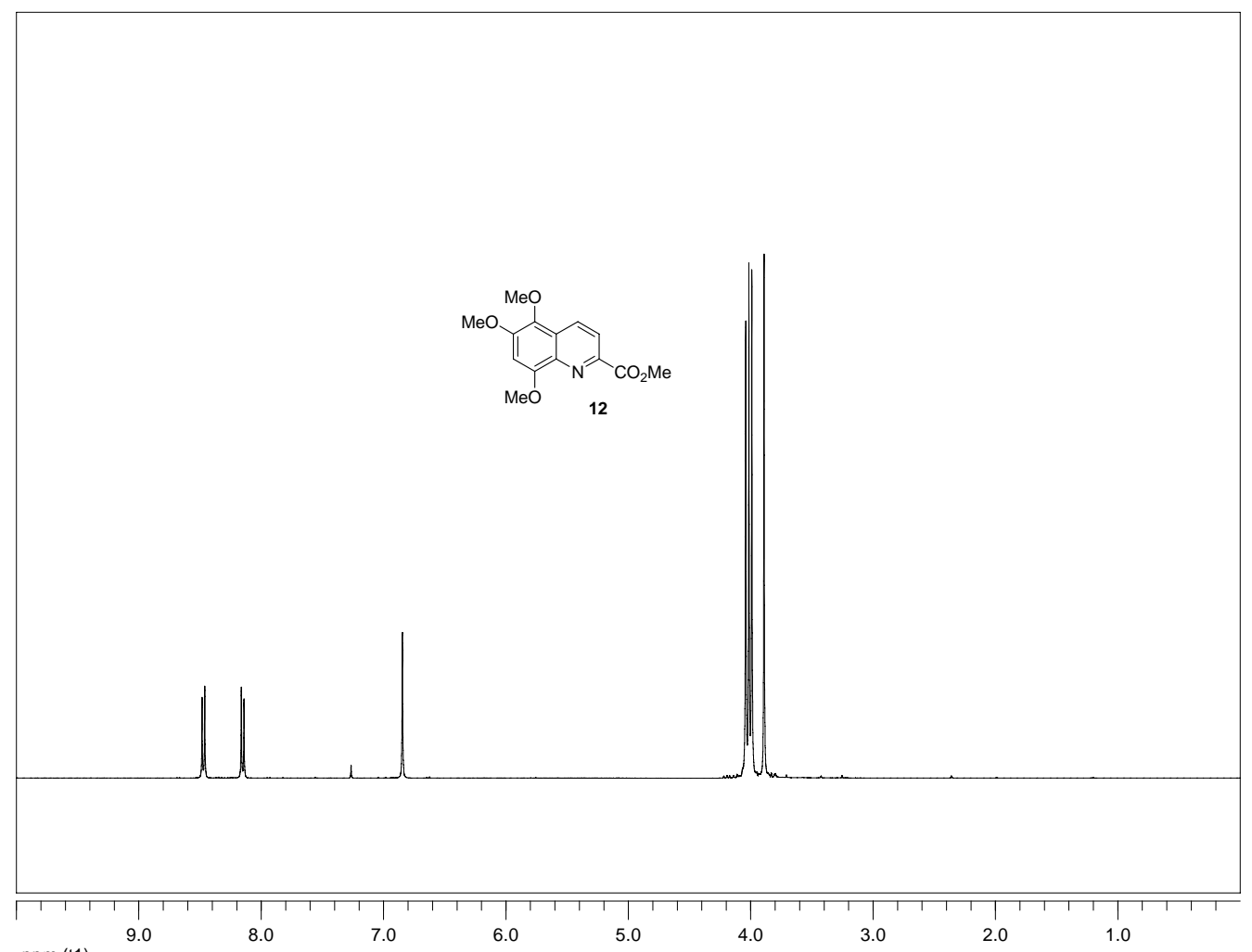

ppm (t1)

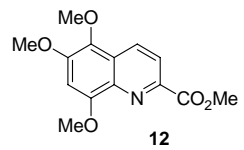

12


ppm (t1) 

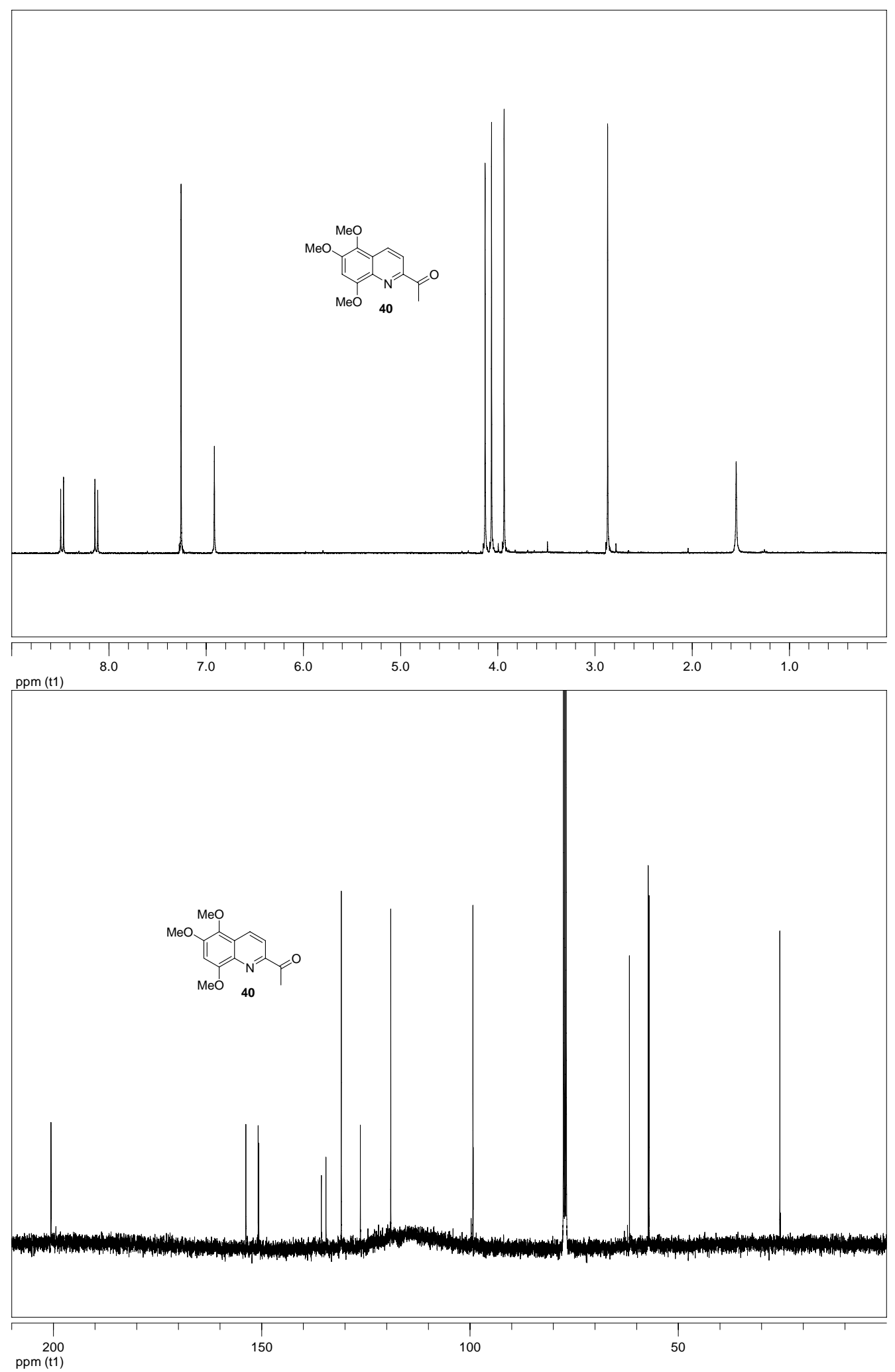

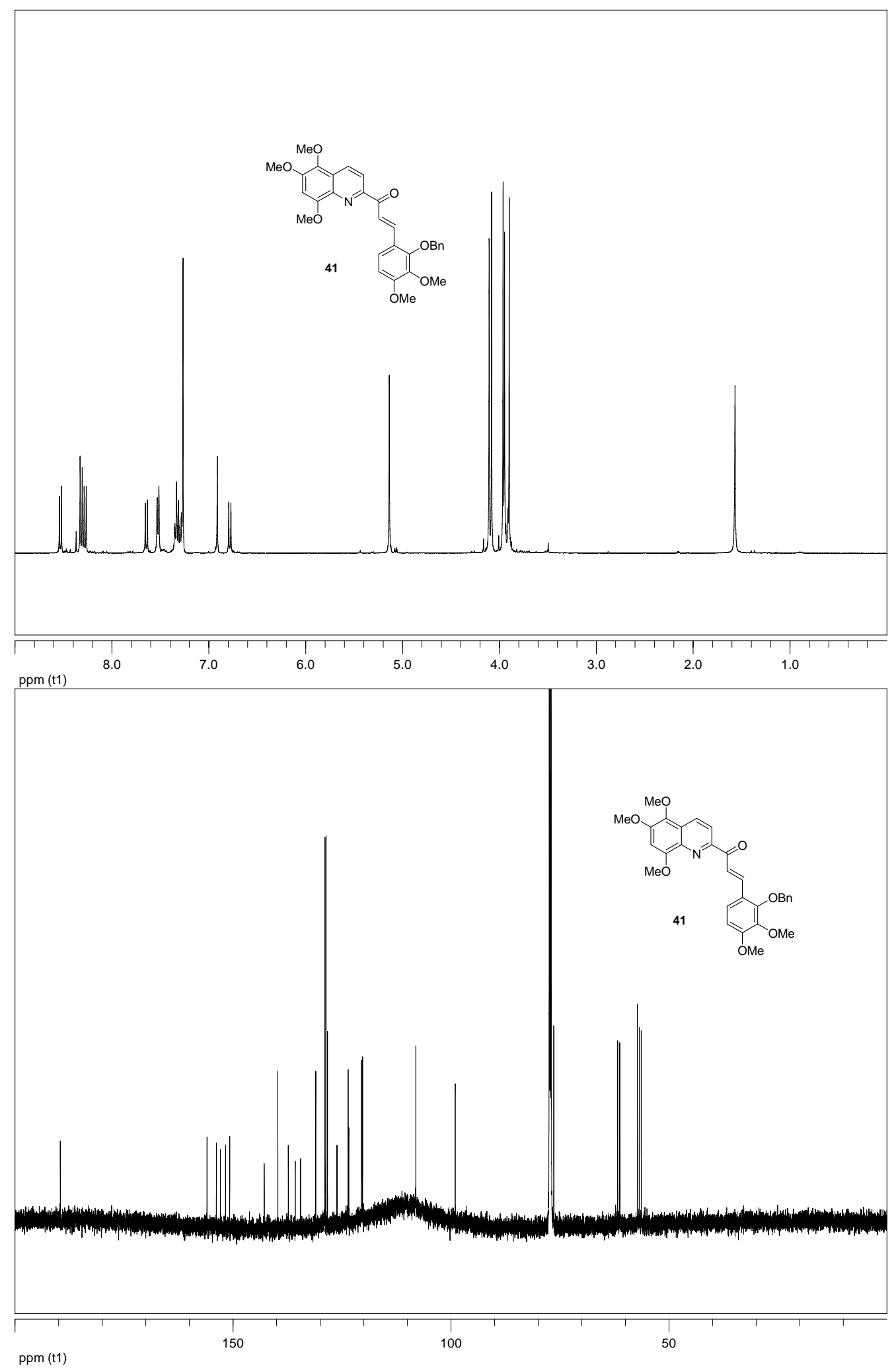

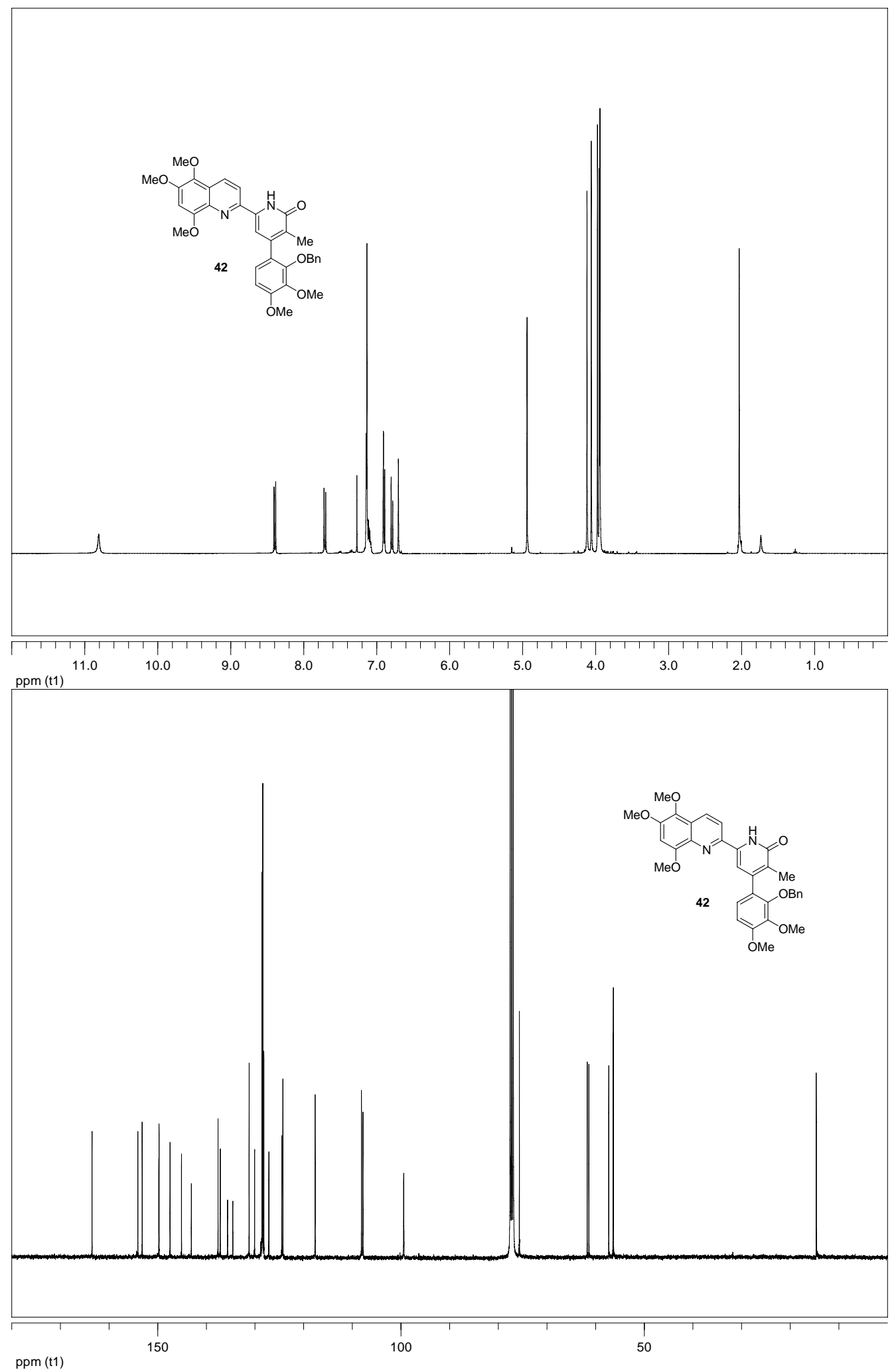

ppm (t1) 

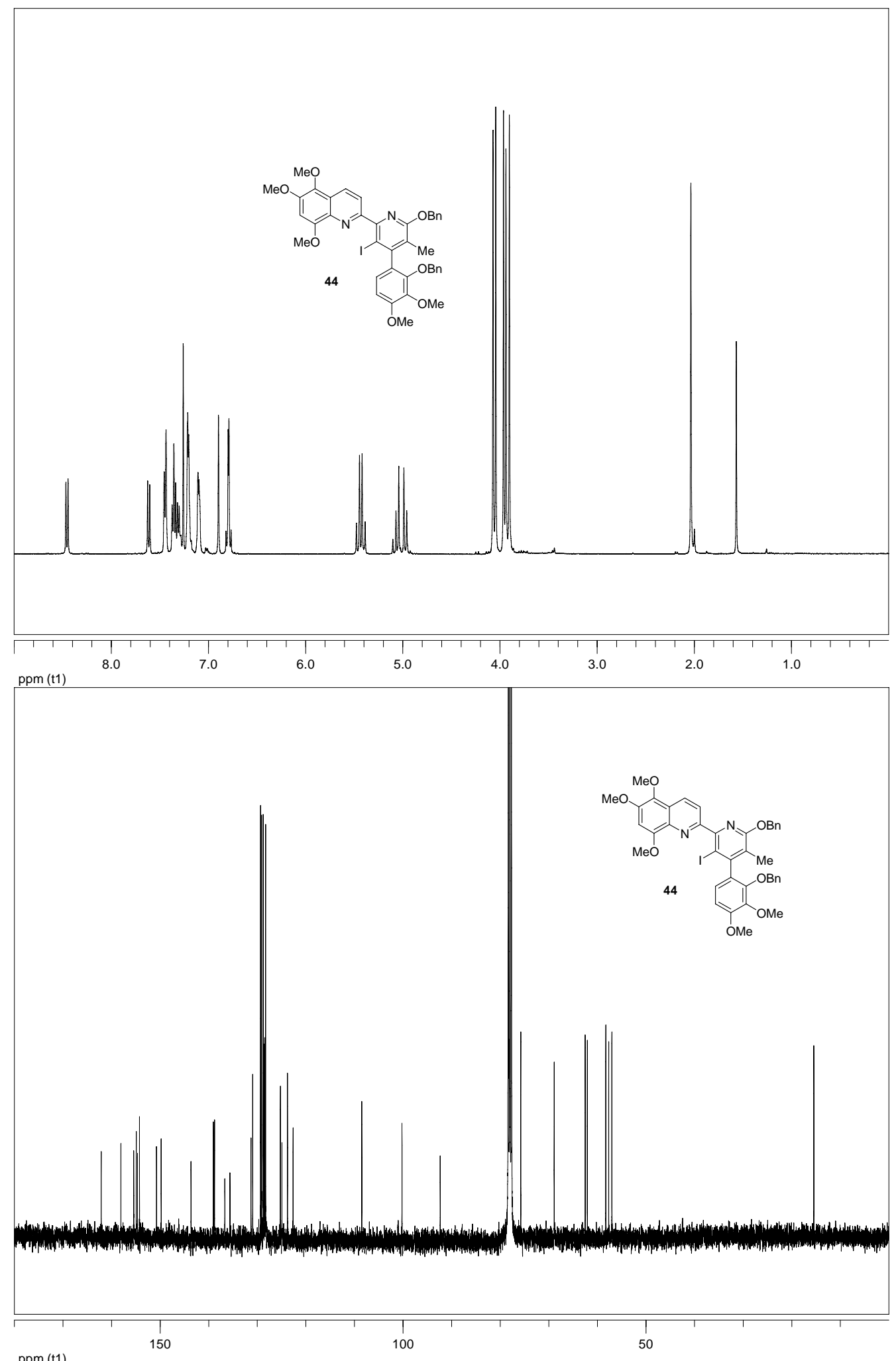

ppm (t1) 

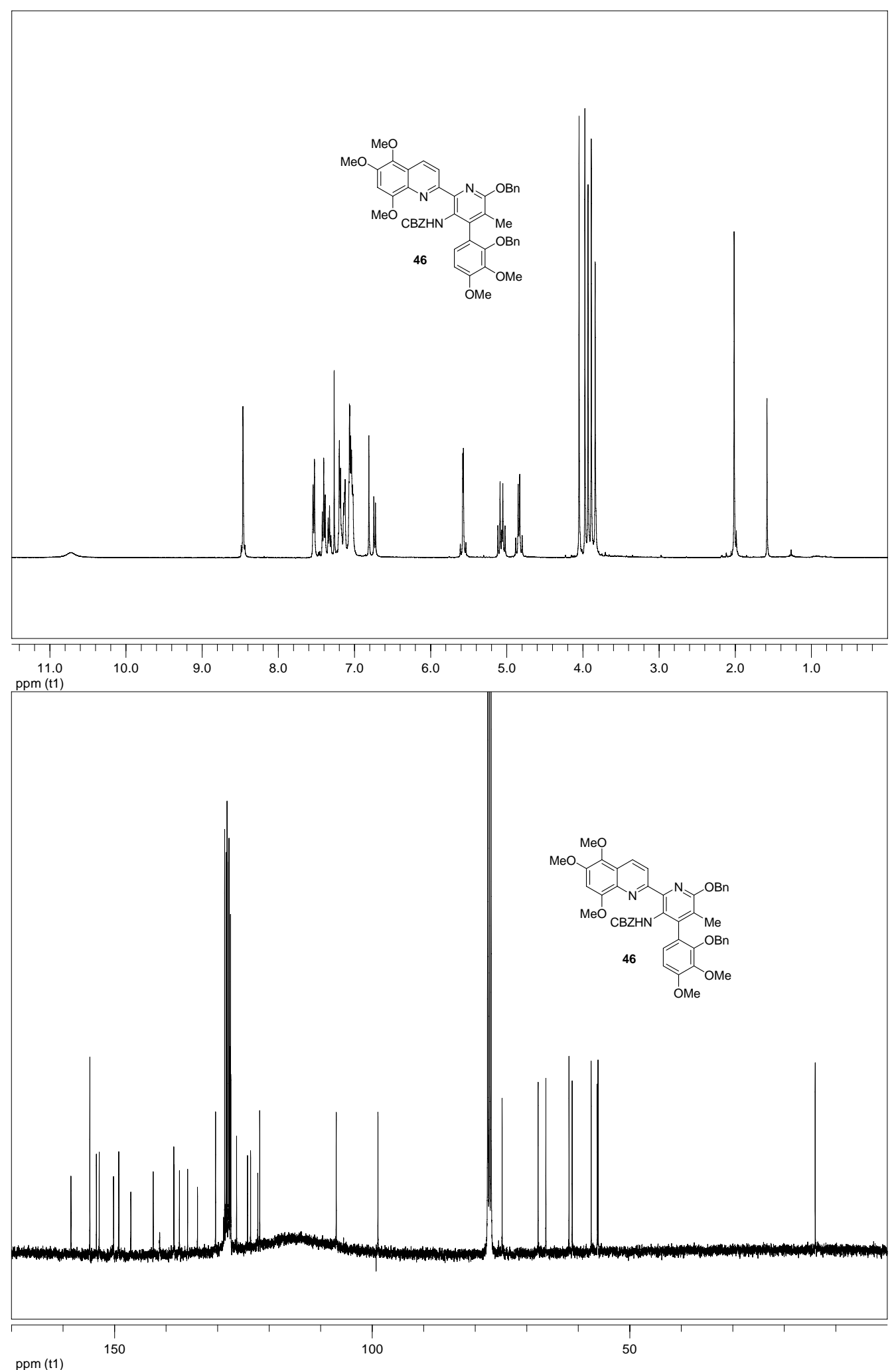

ppm (t1) 

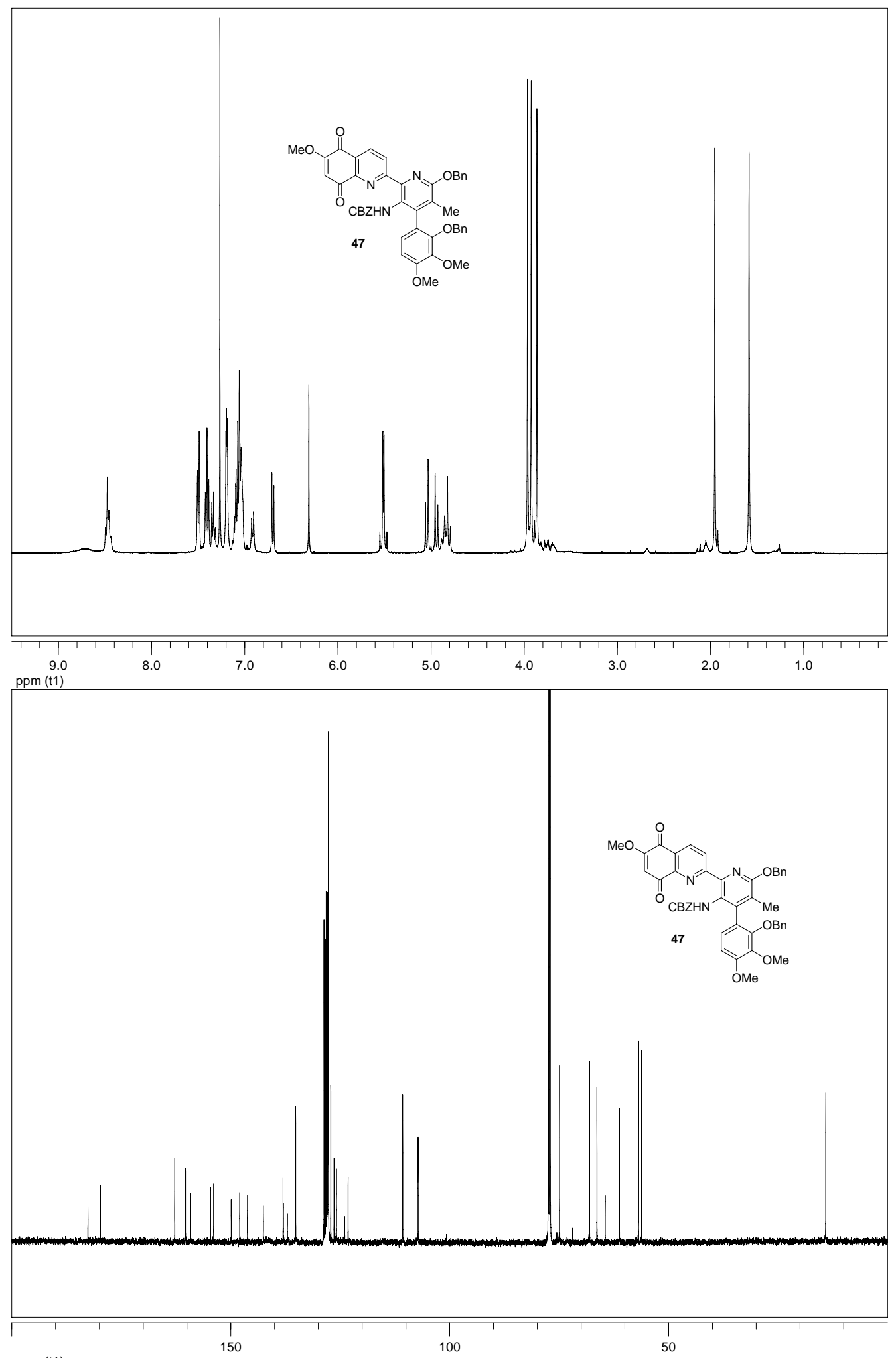

ppm (t1) 

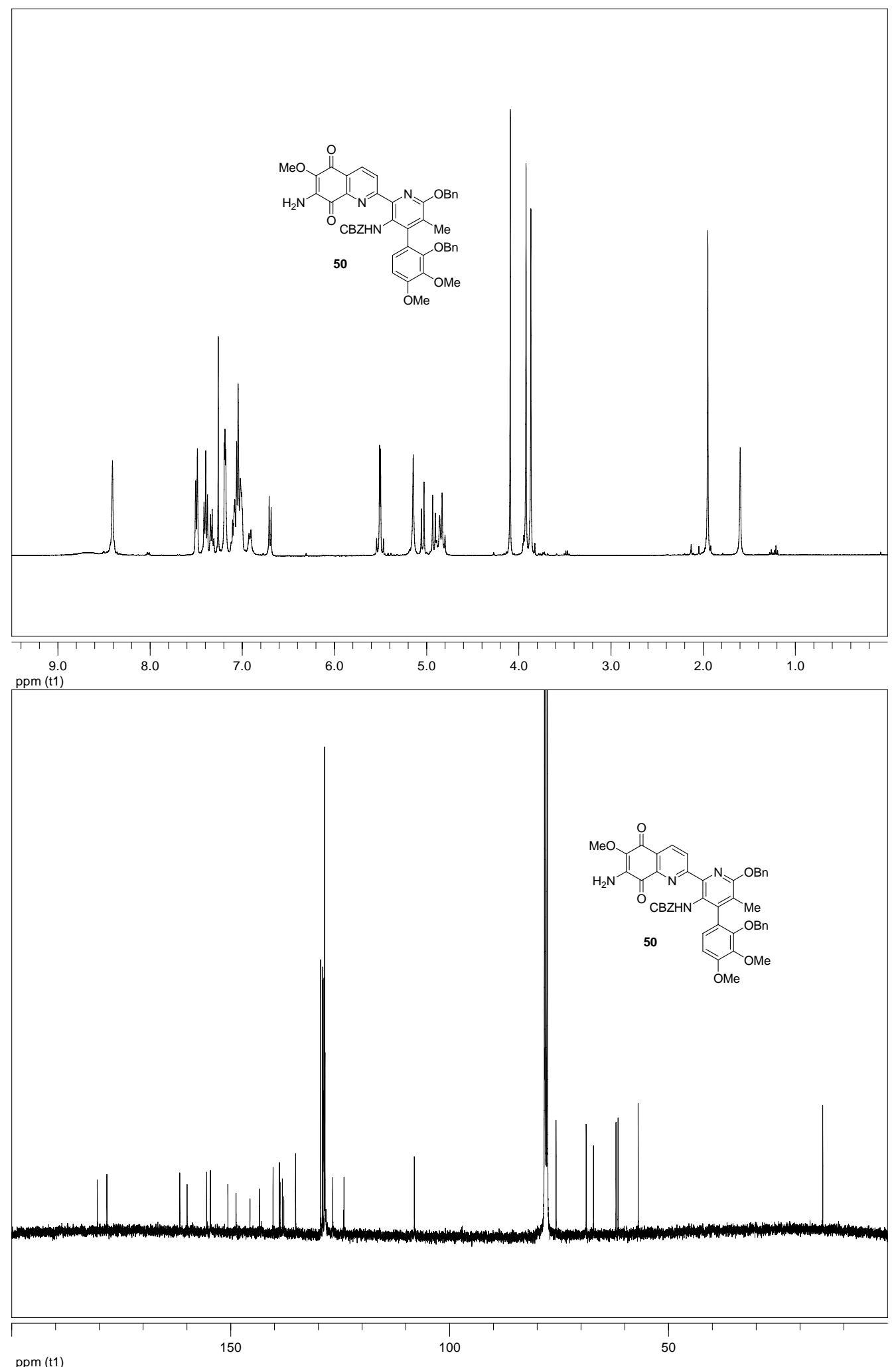

ppm (t1) 

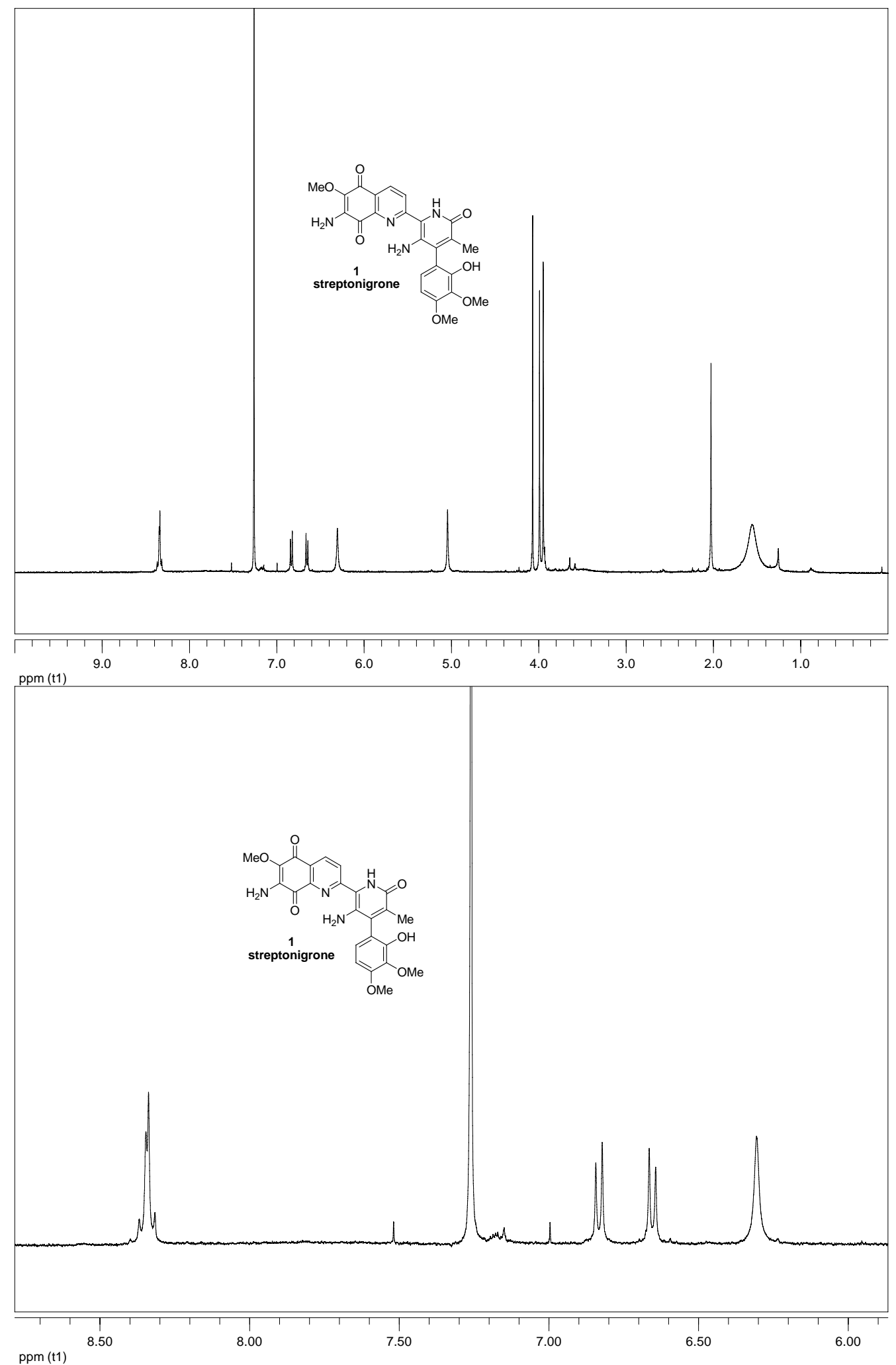

ppm (t1) 

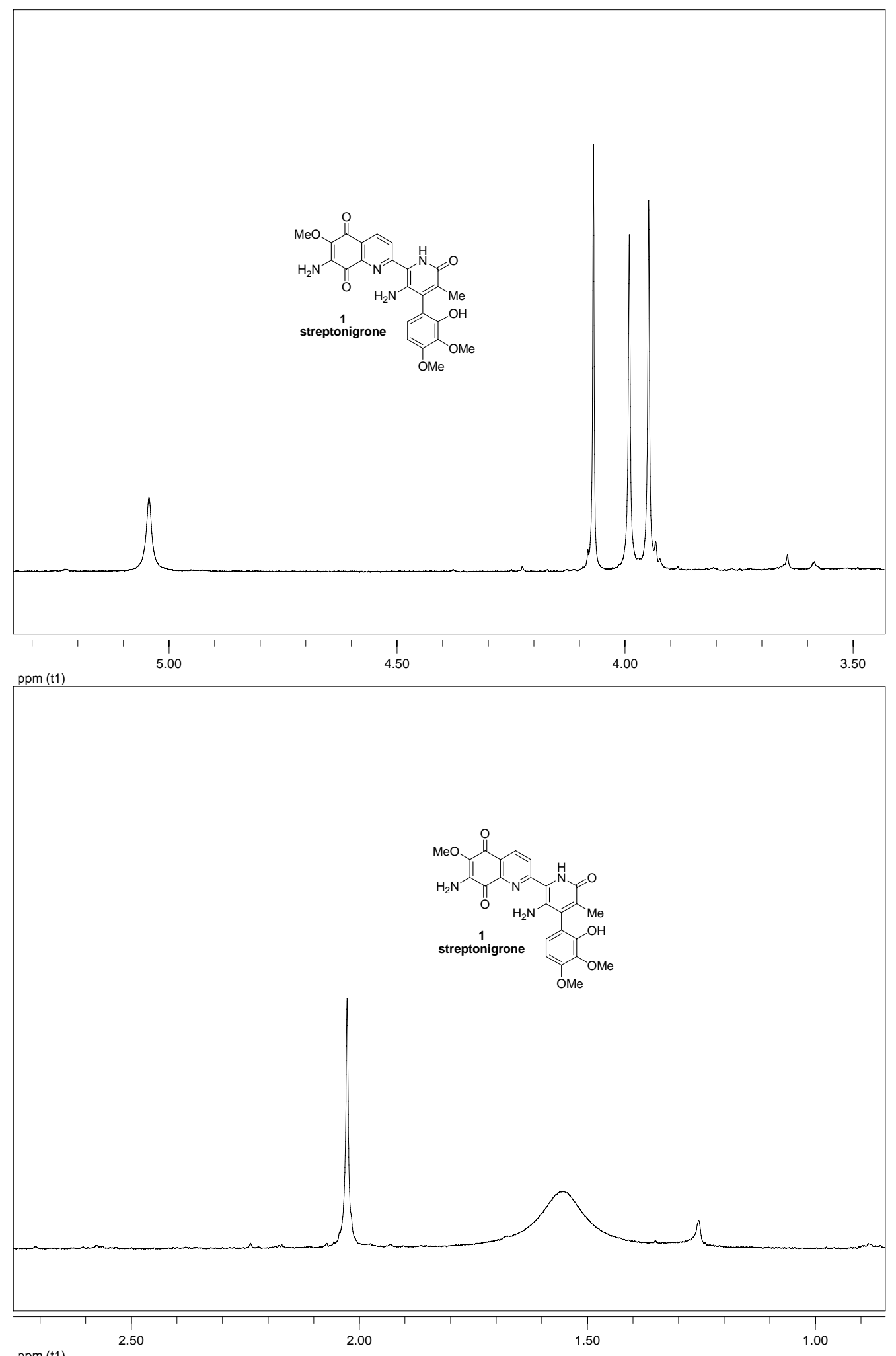

ppm (t1) 

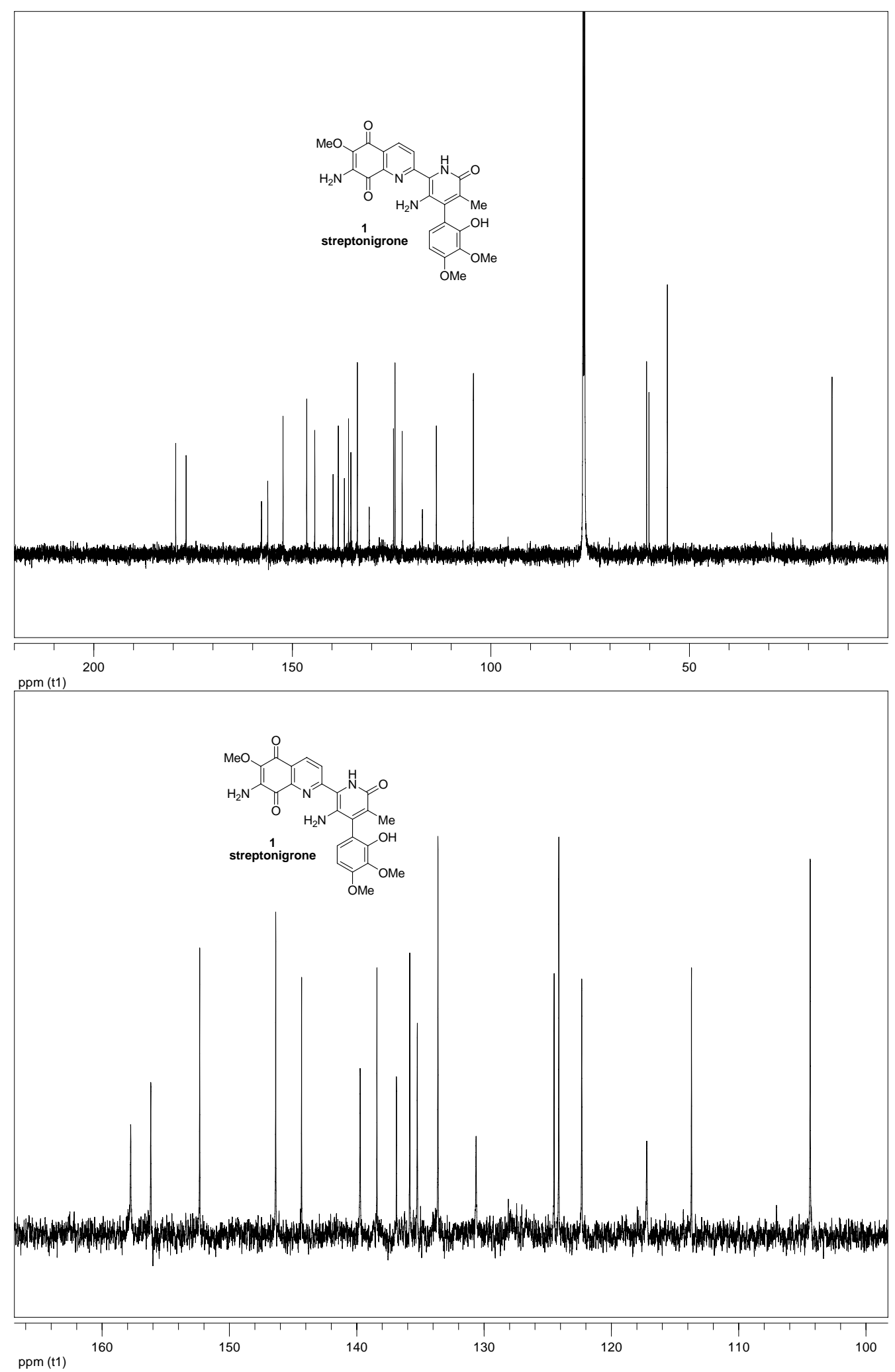


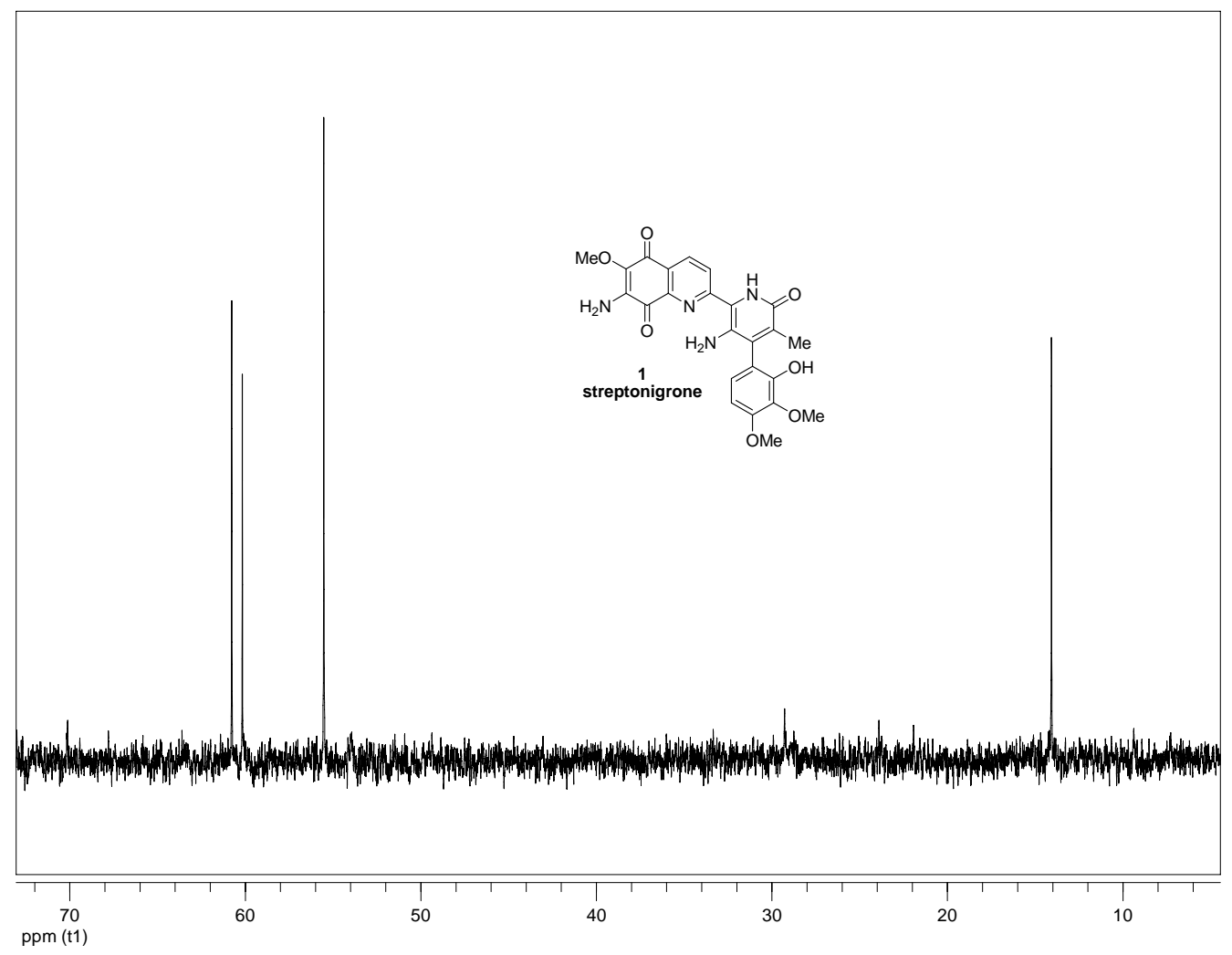



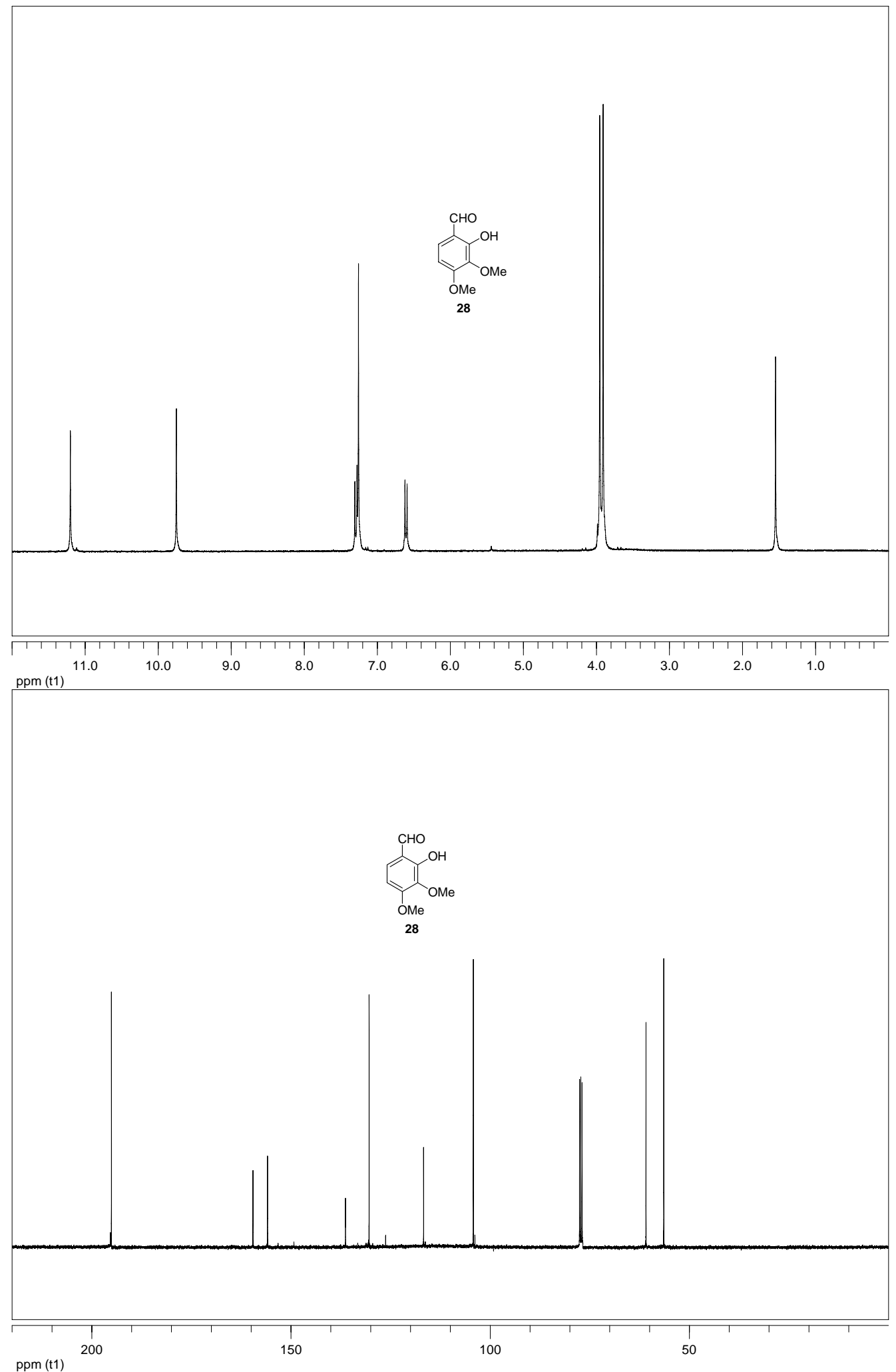

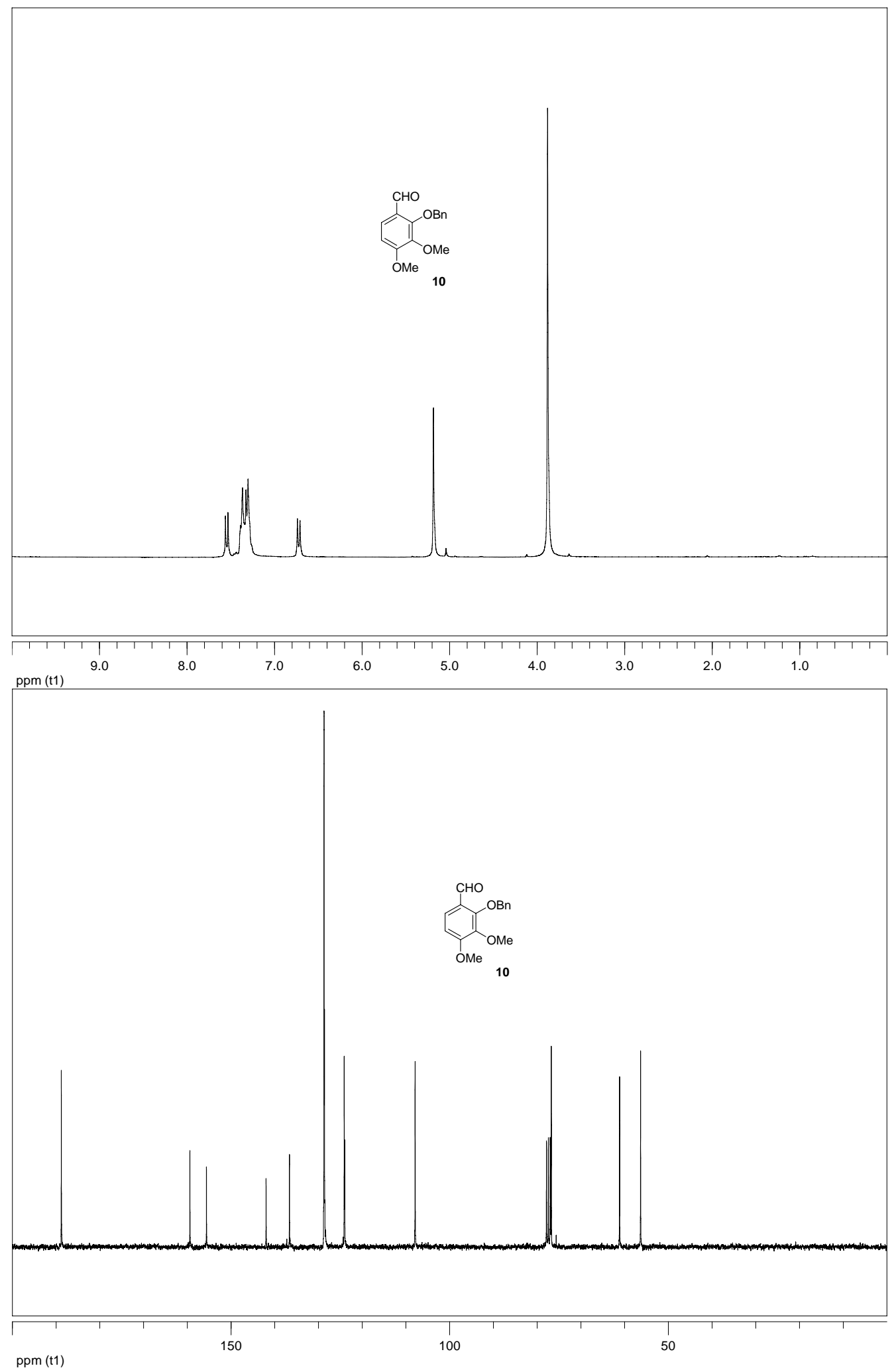

ppm (t1) 

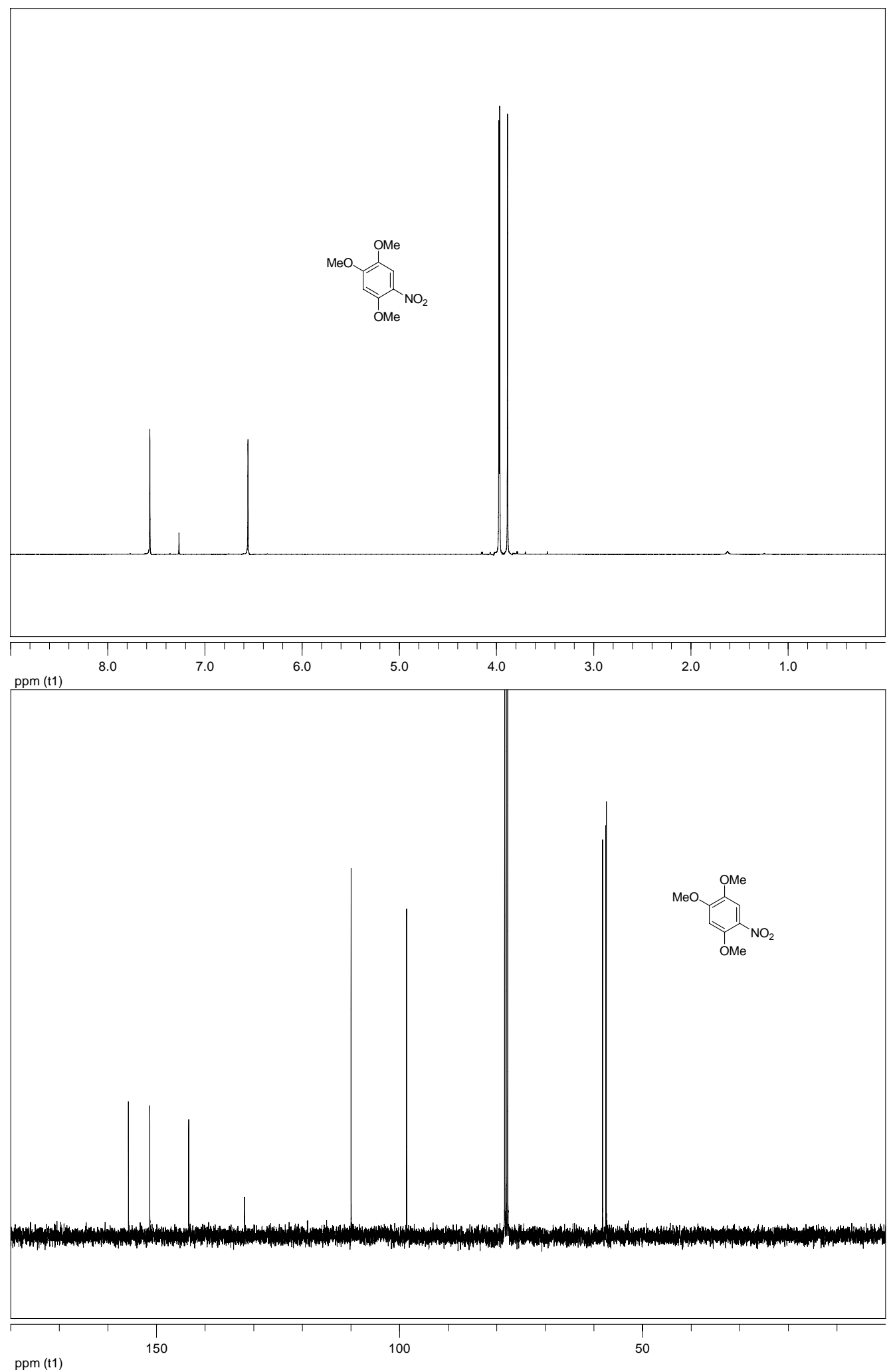

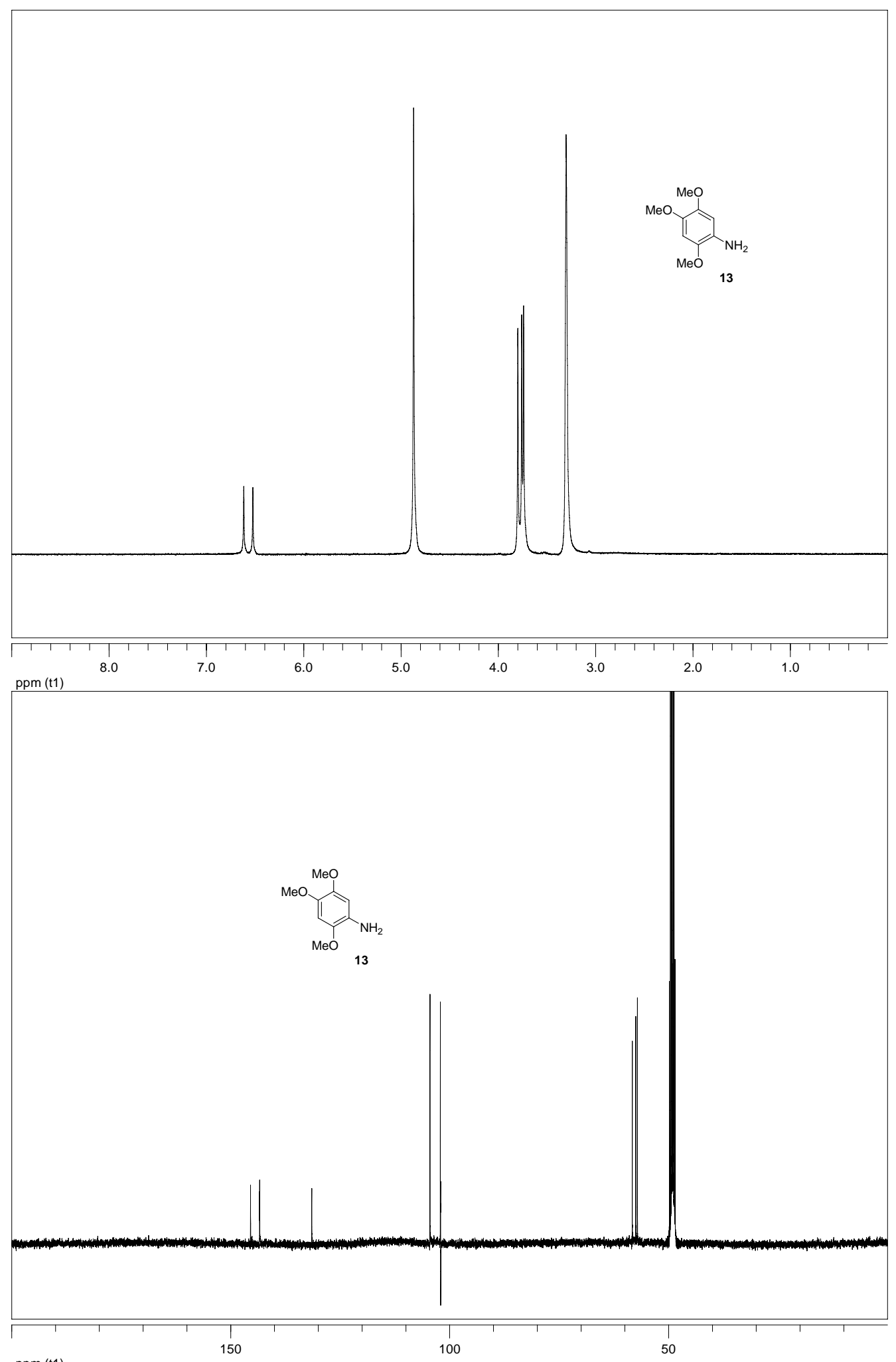

ppm (t1) 

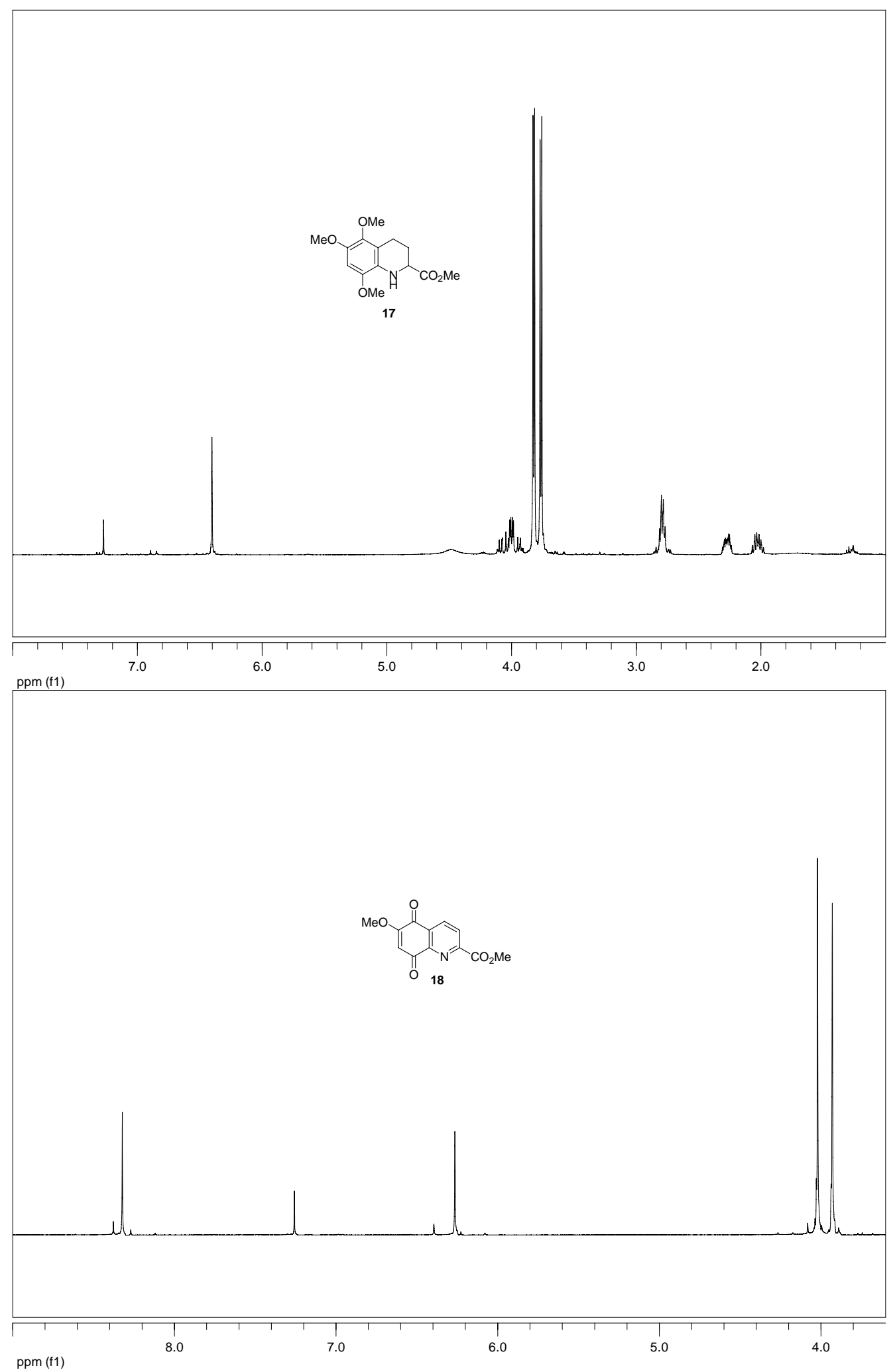

ppm (f1) 

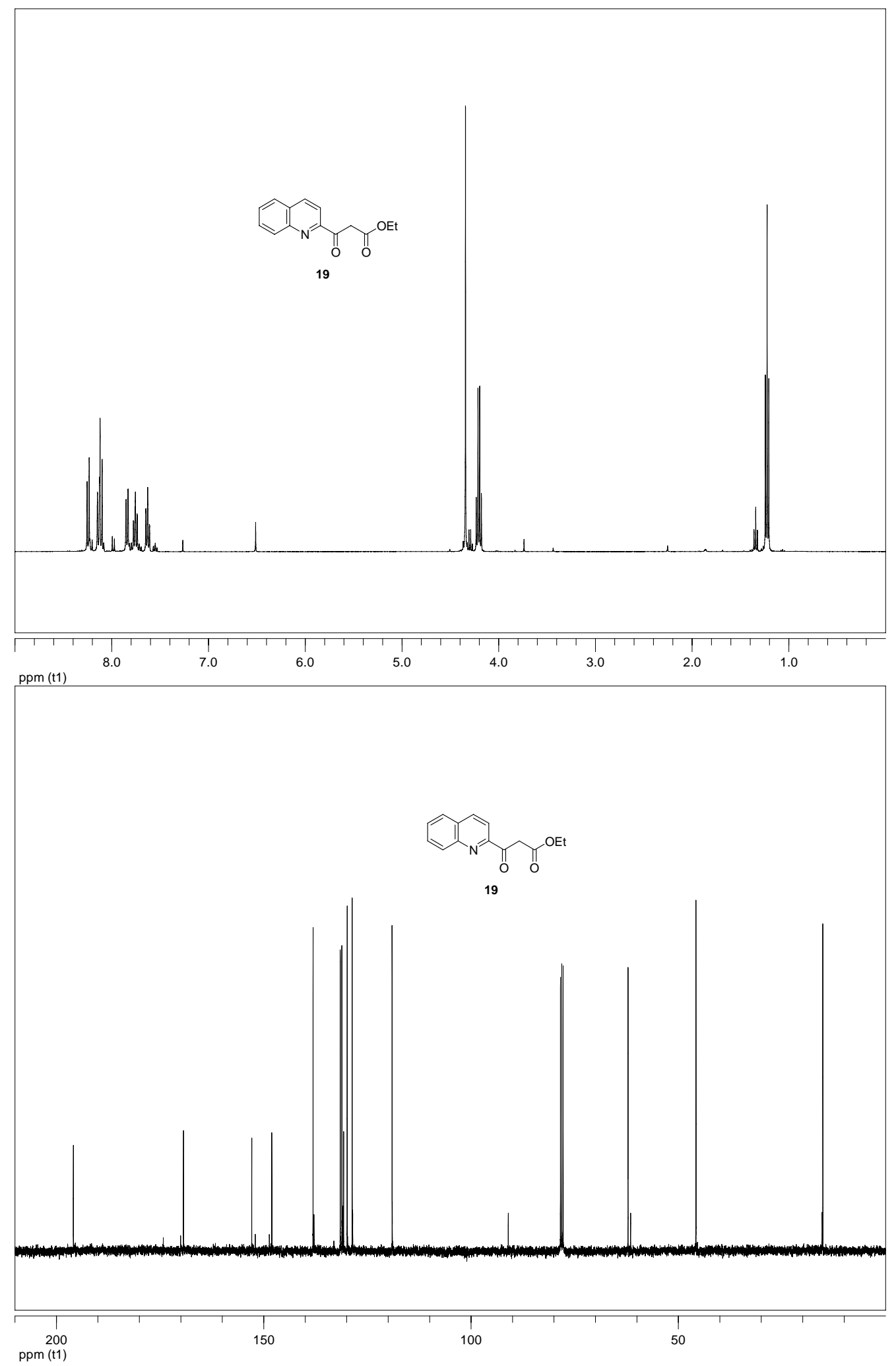


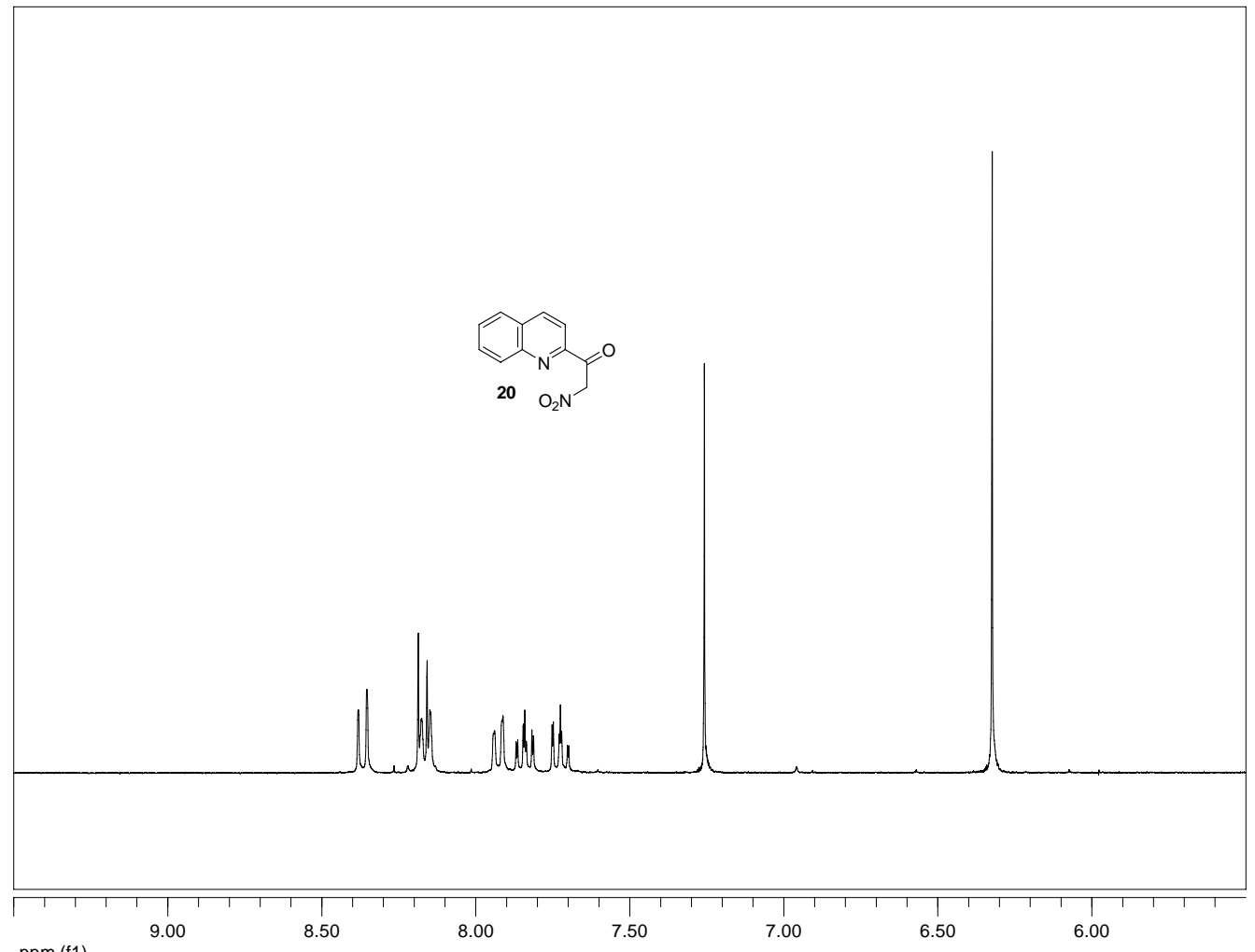

ppm (f1) 

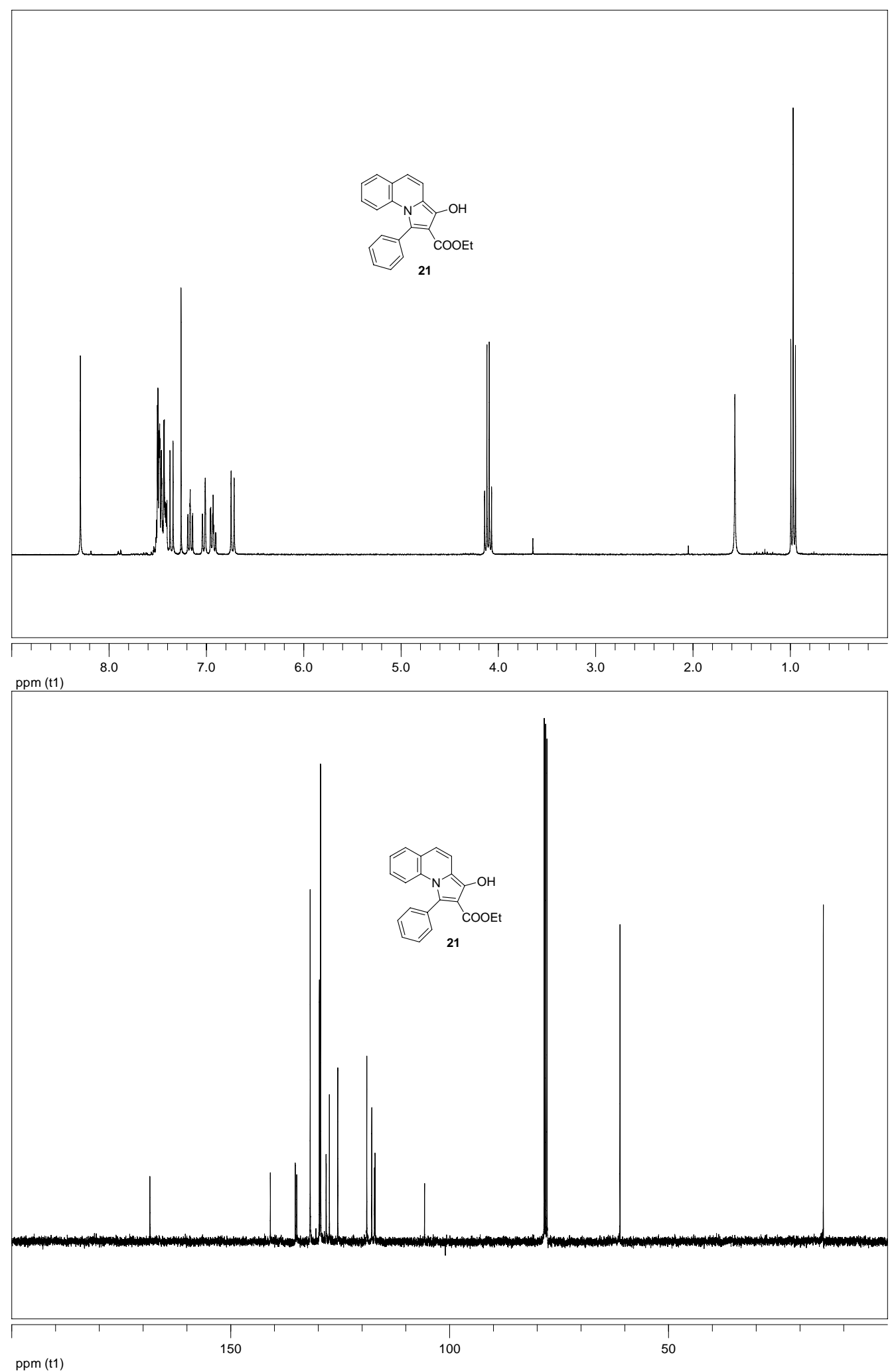

ppm (t1) 
Chan and Ciufolini

Synthesis of Streptonigrone

S32
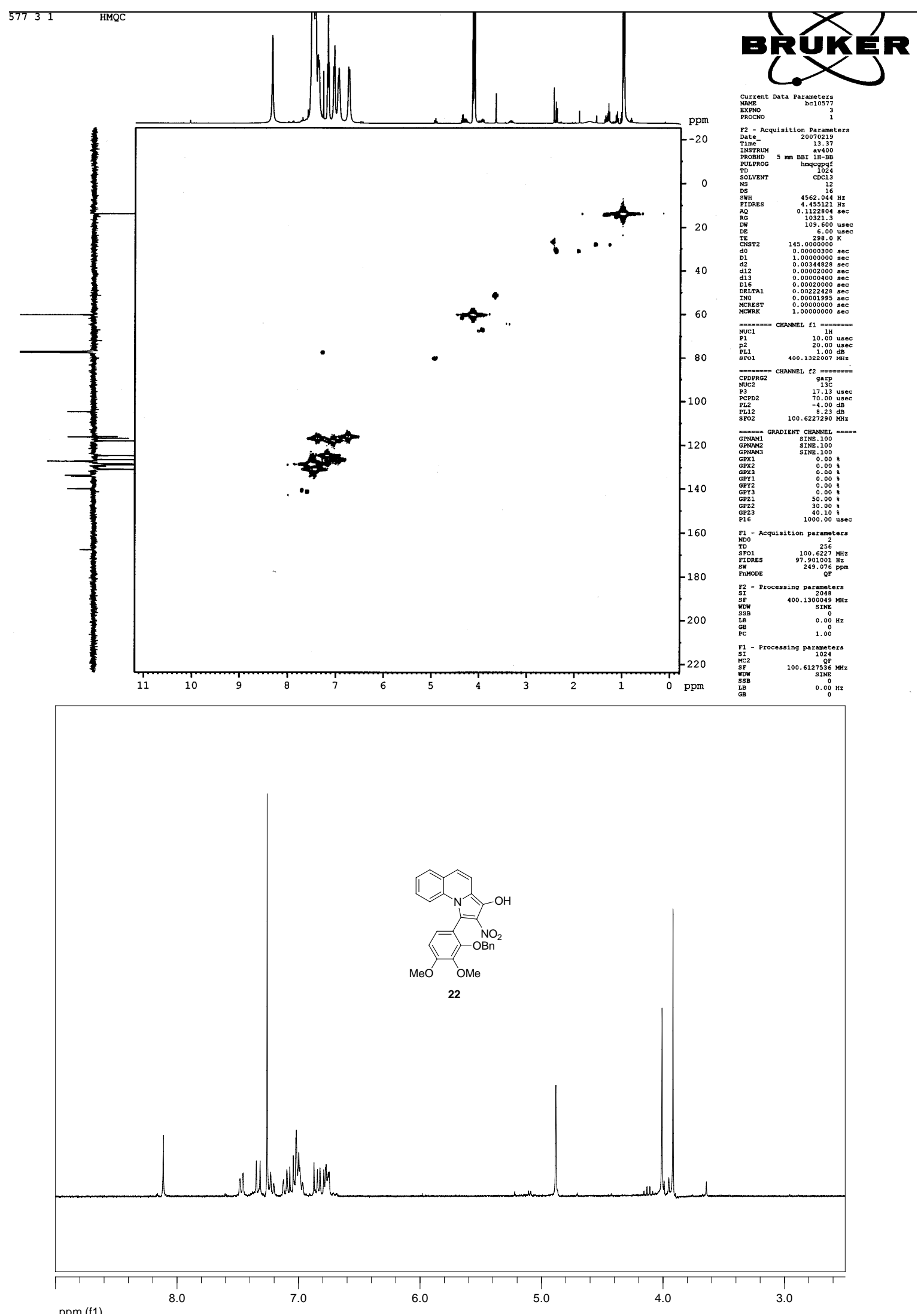

ppm (f1) 

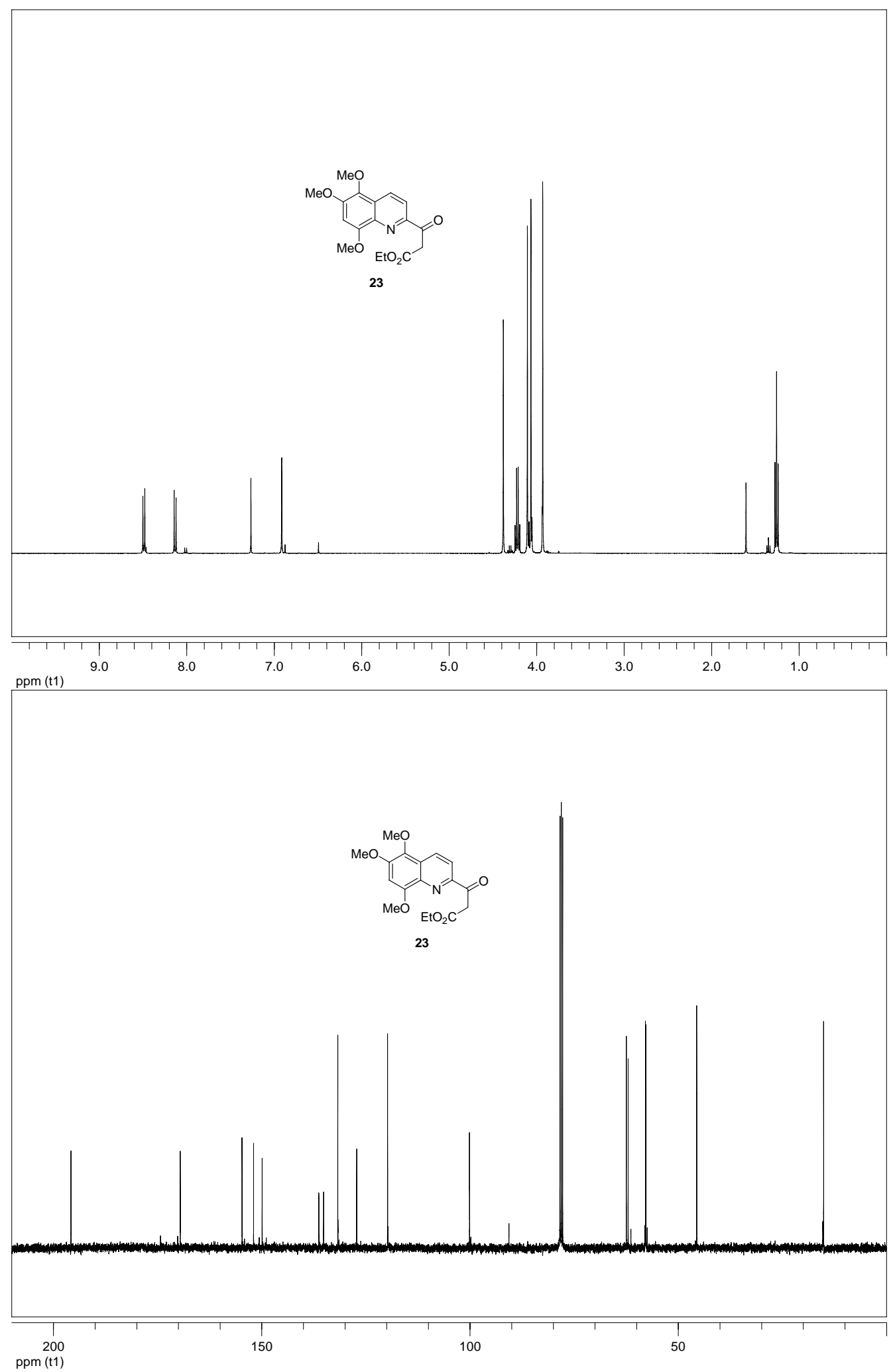

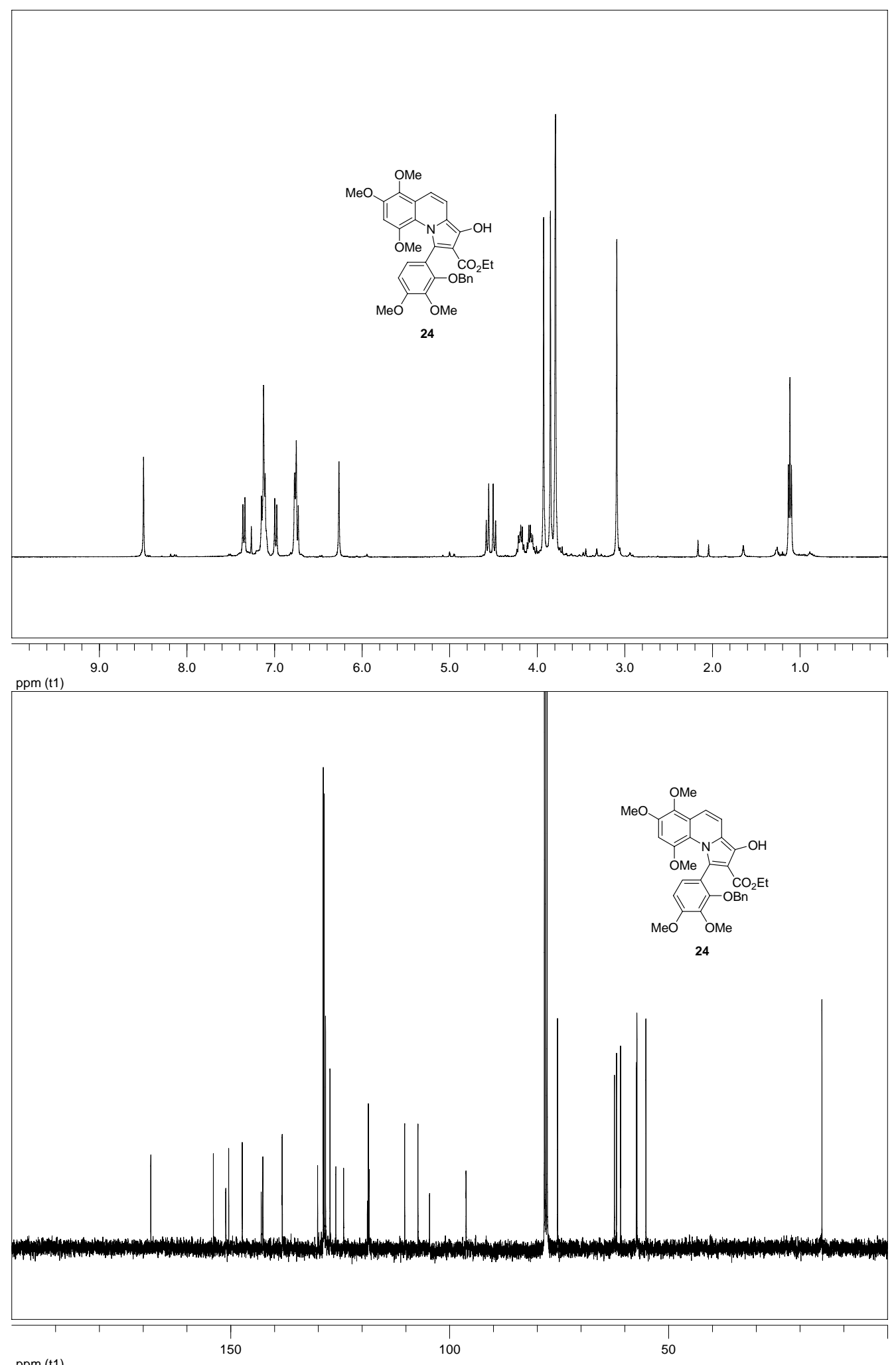

ppm (t1) 


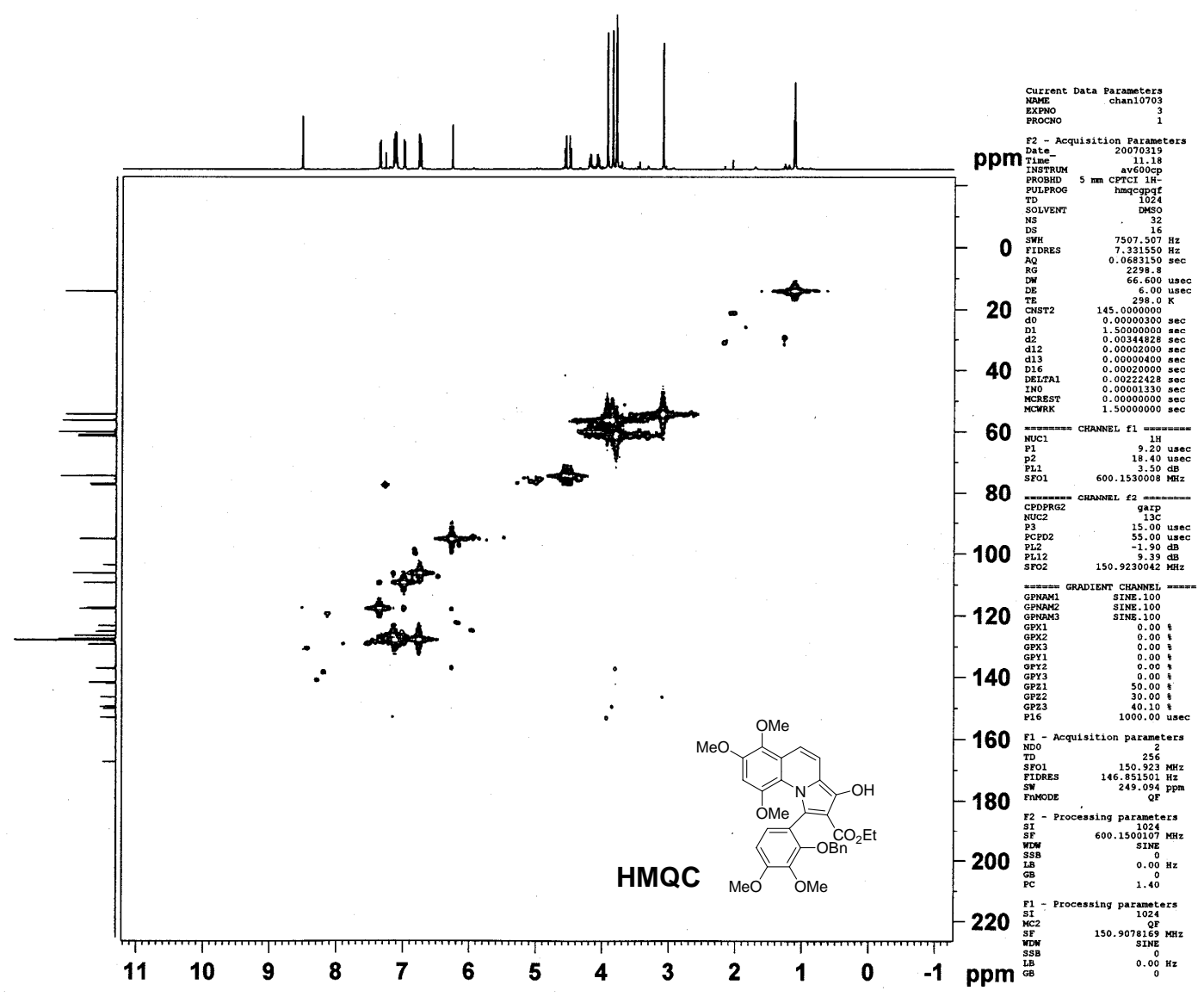









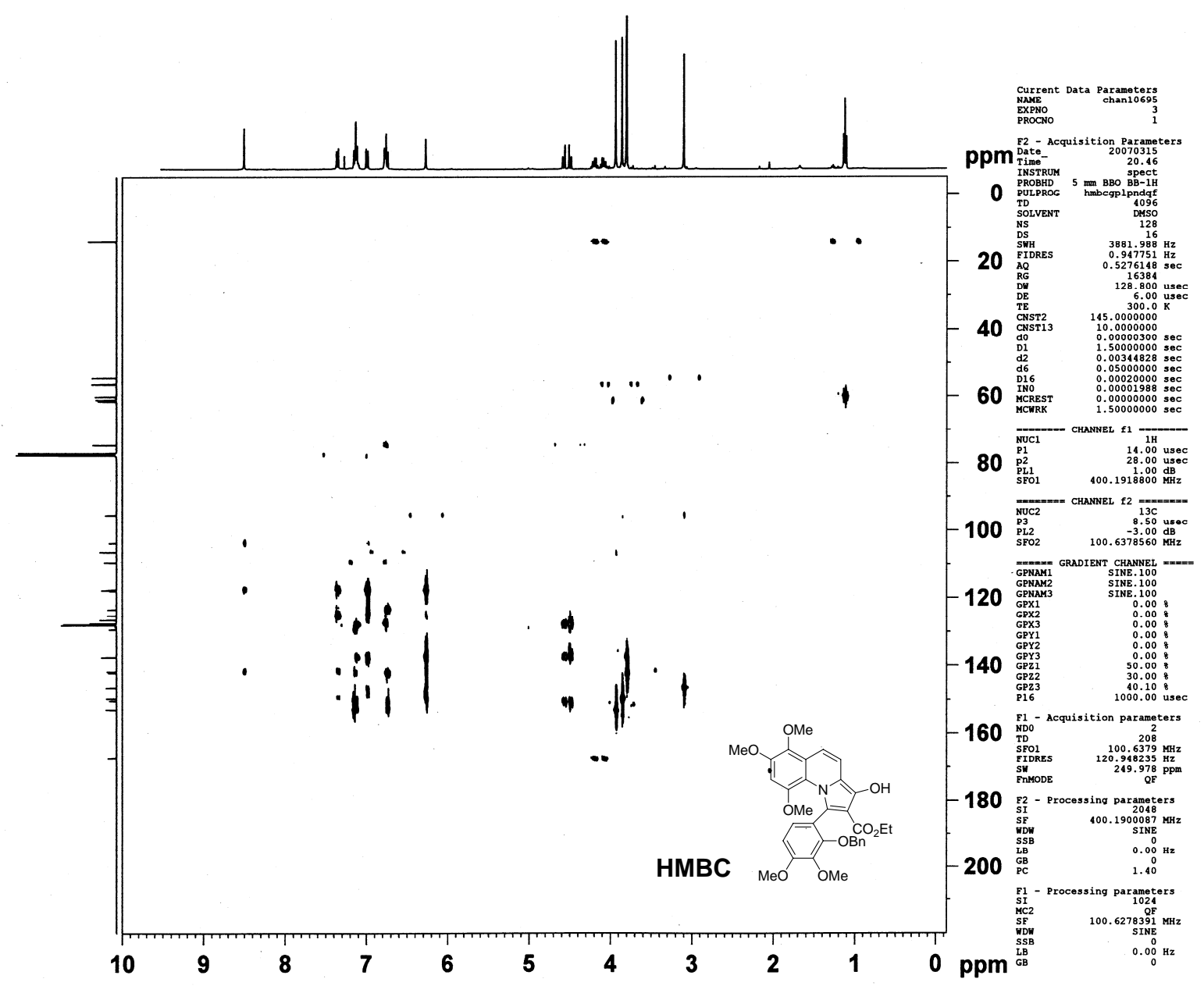




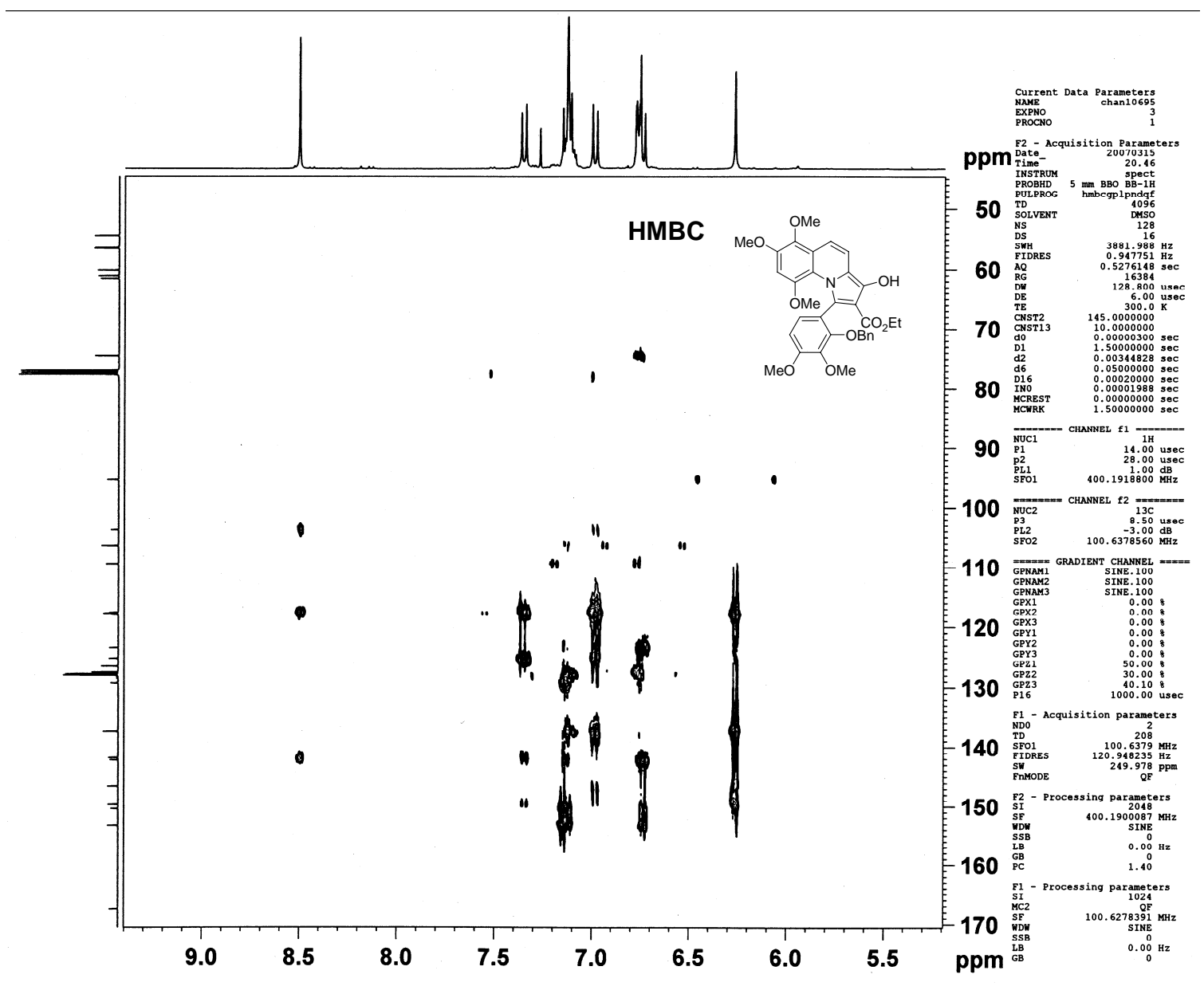



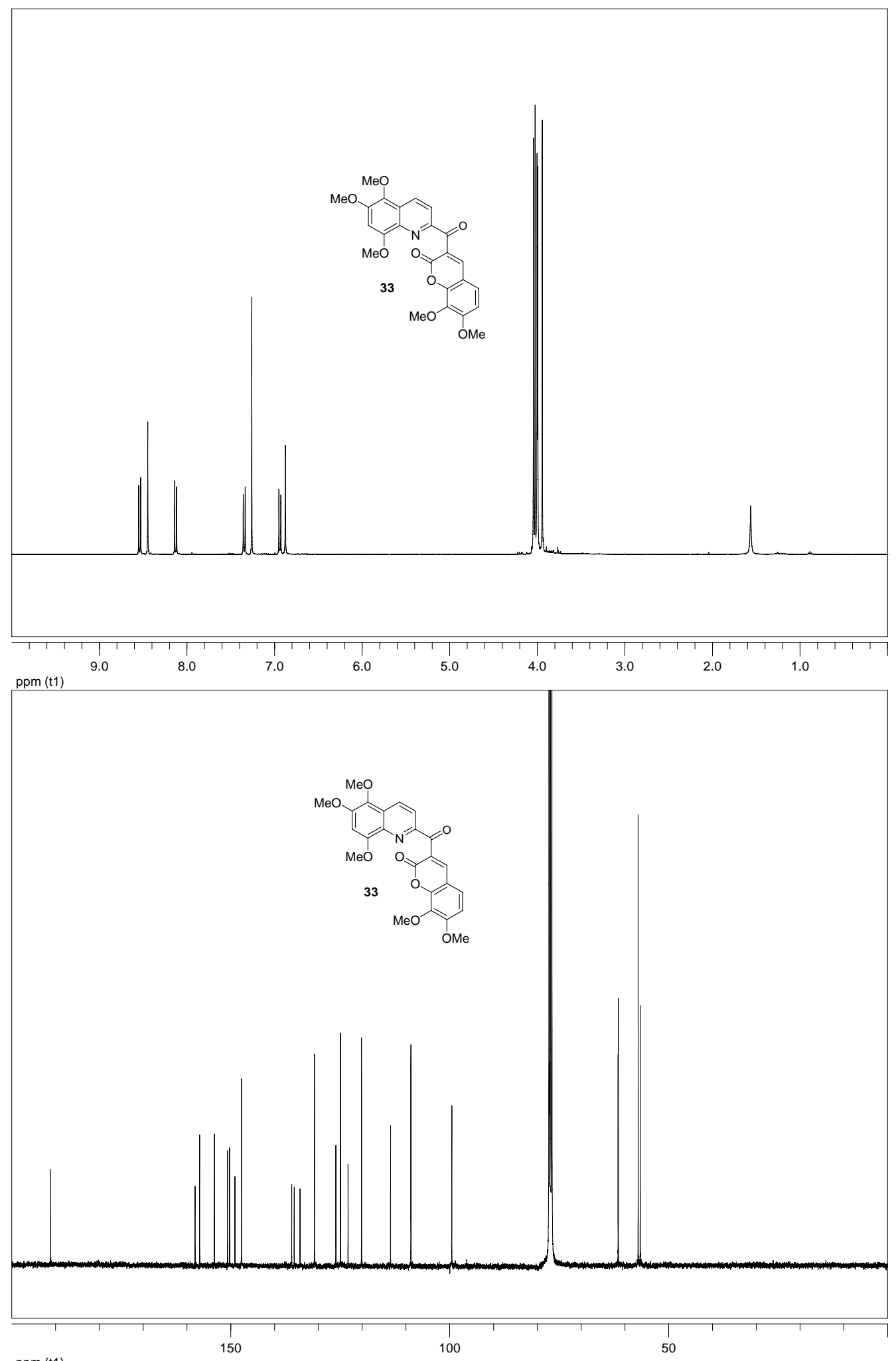

ppm (t1) 


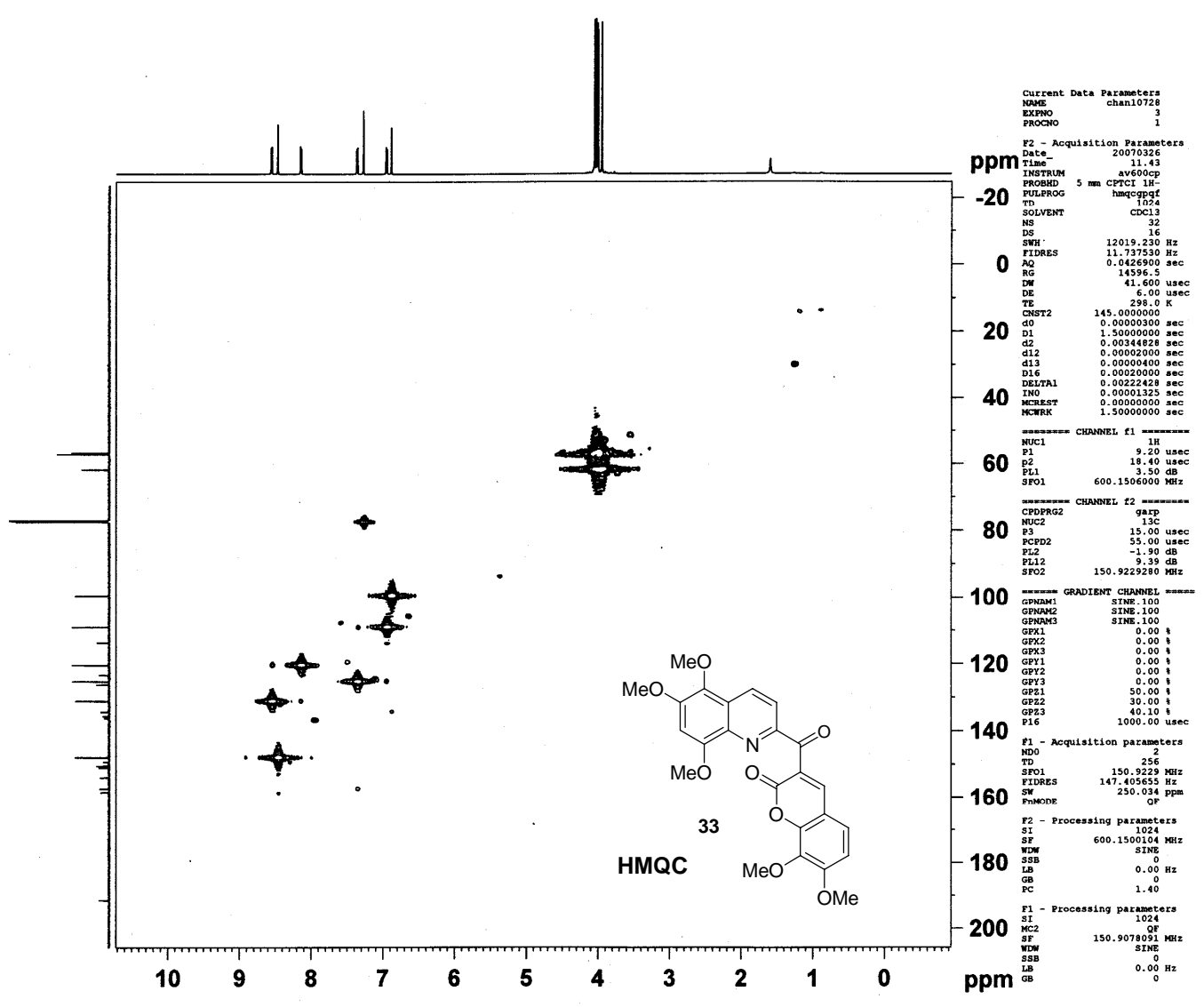



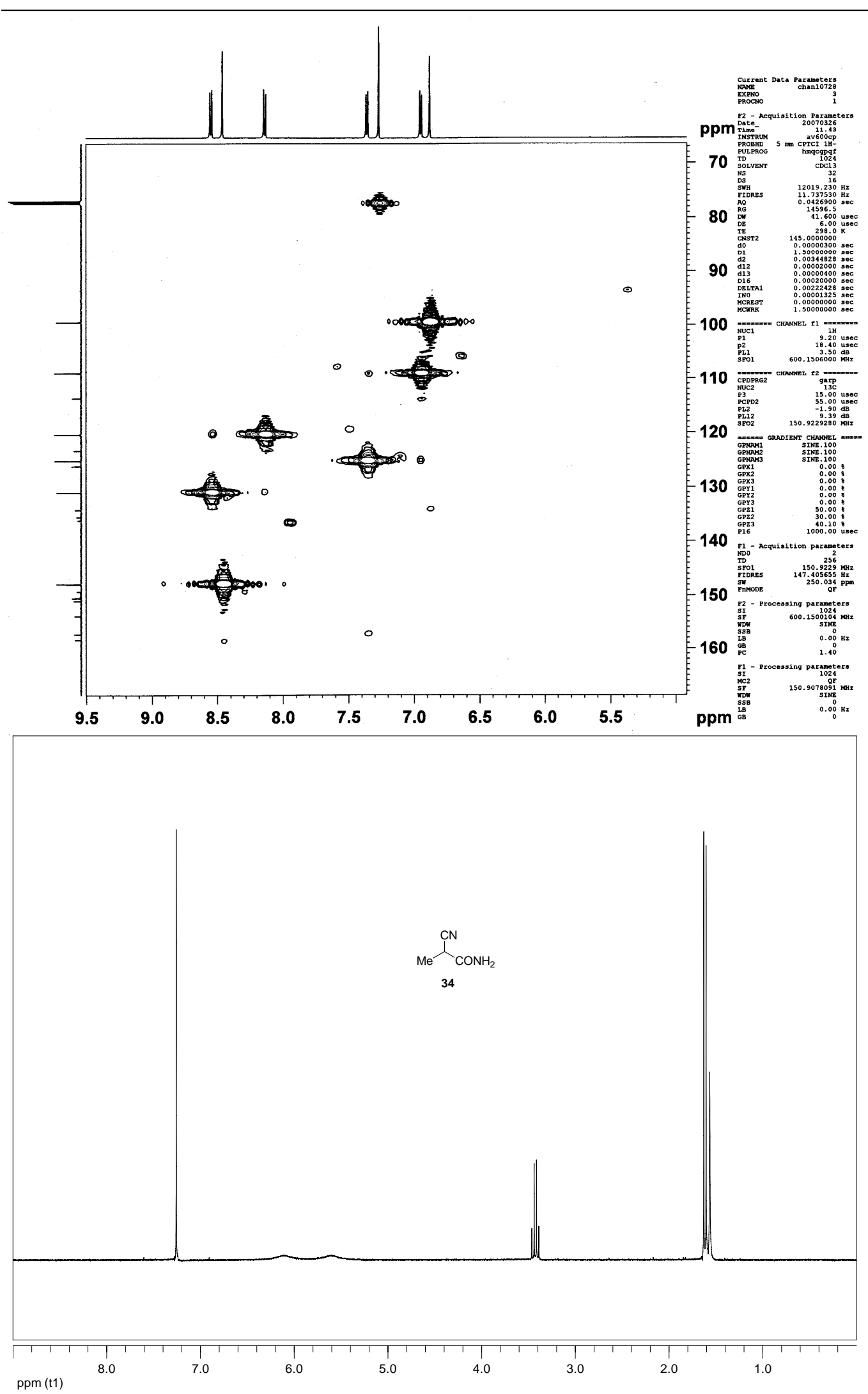

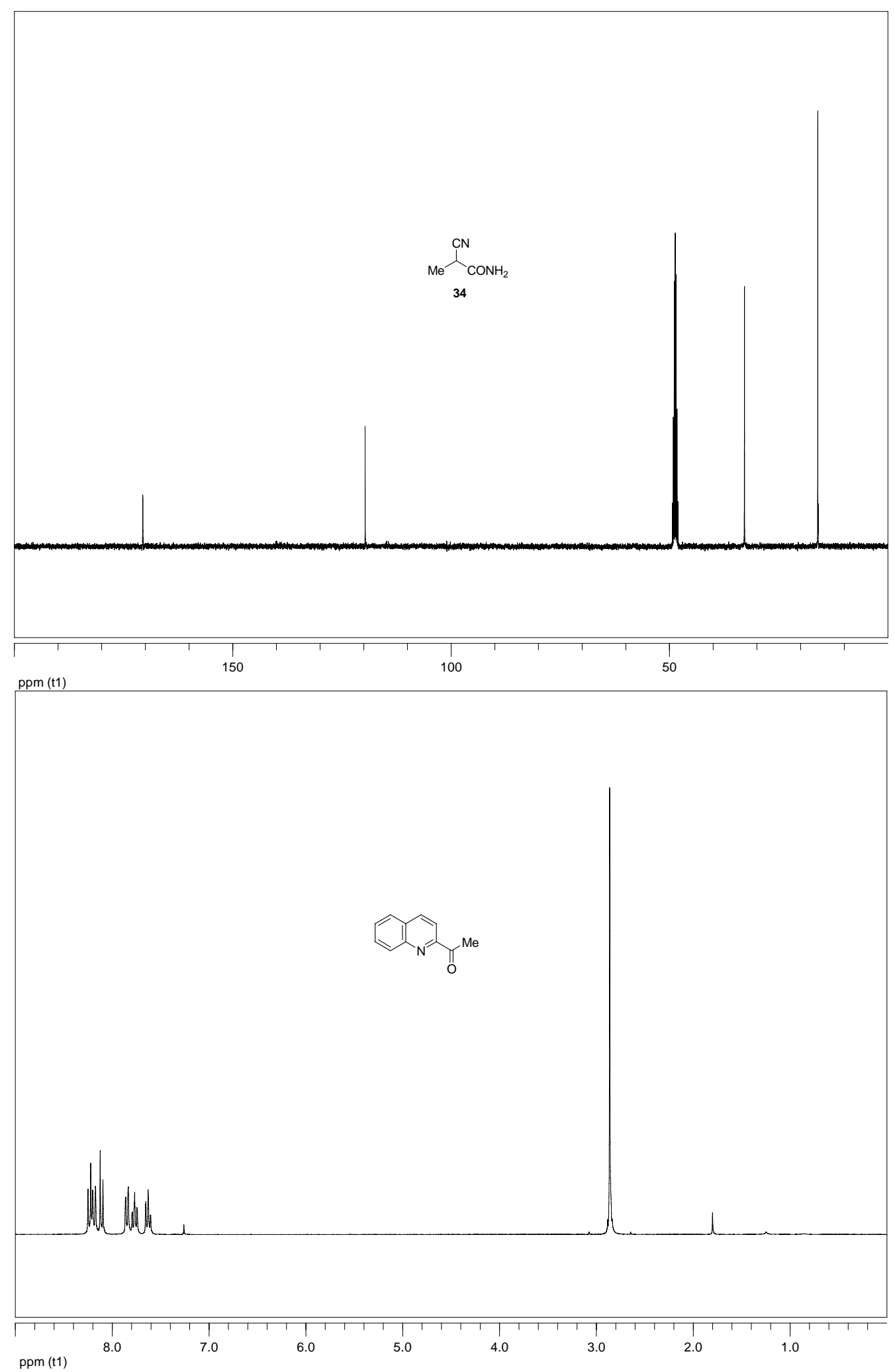

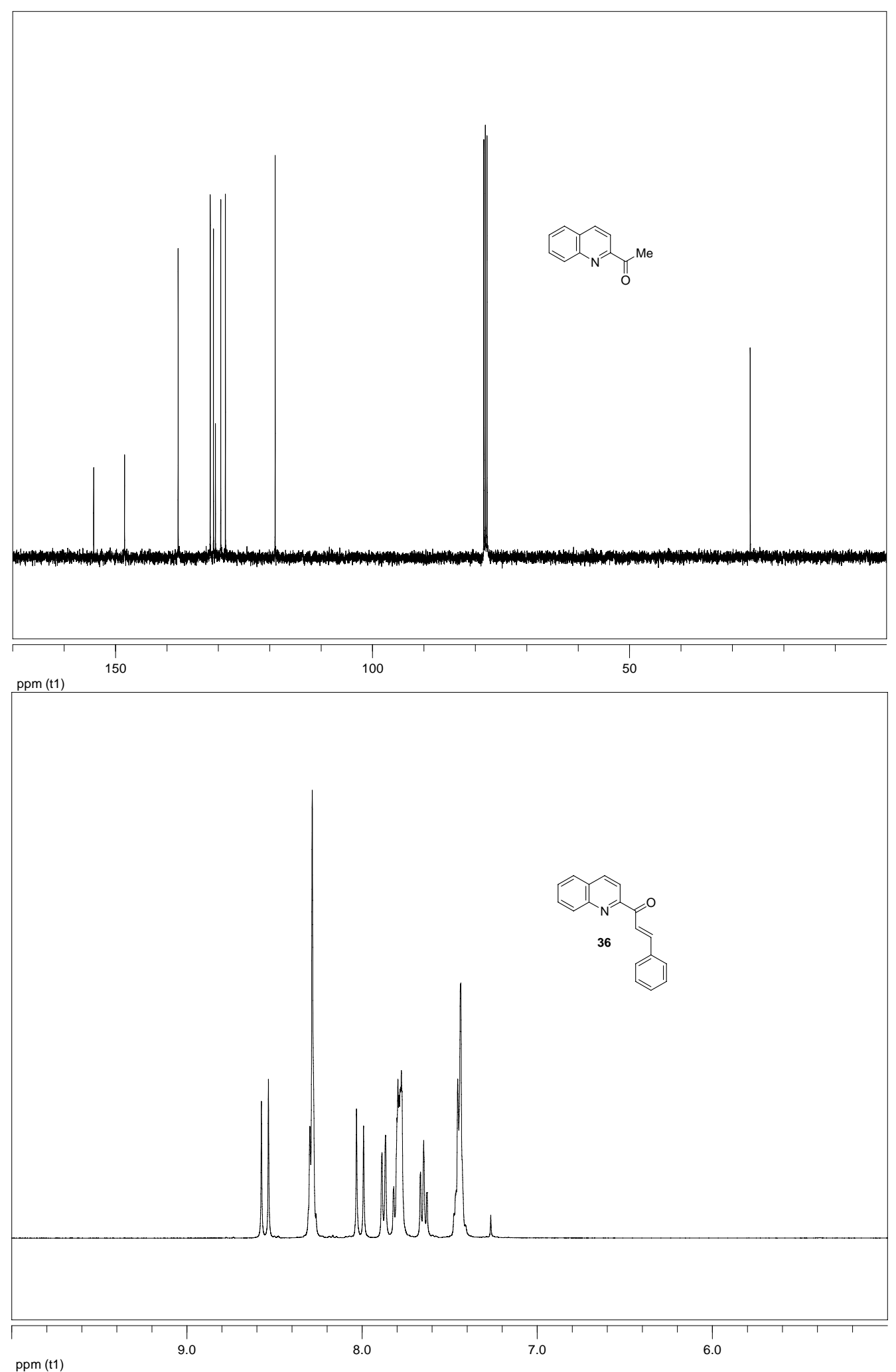

ppm (t1) 

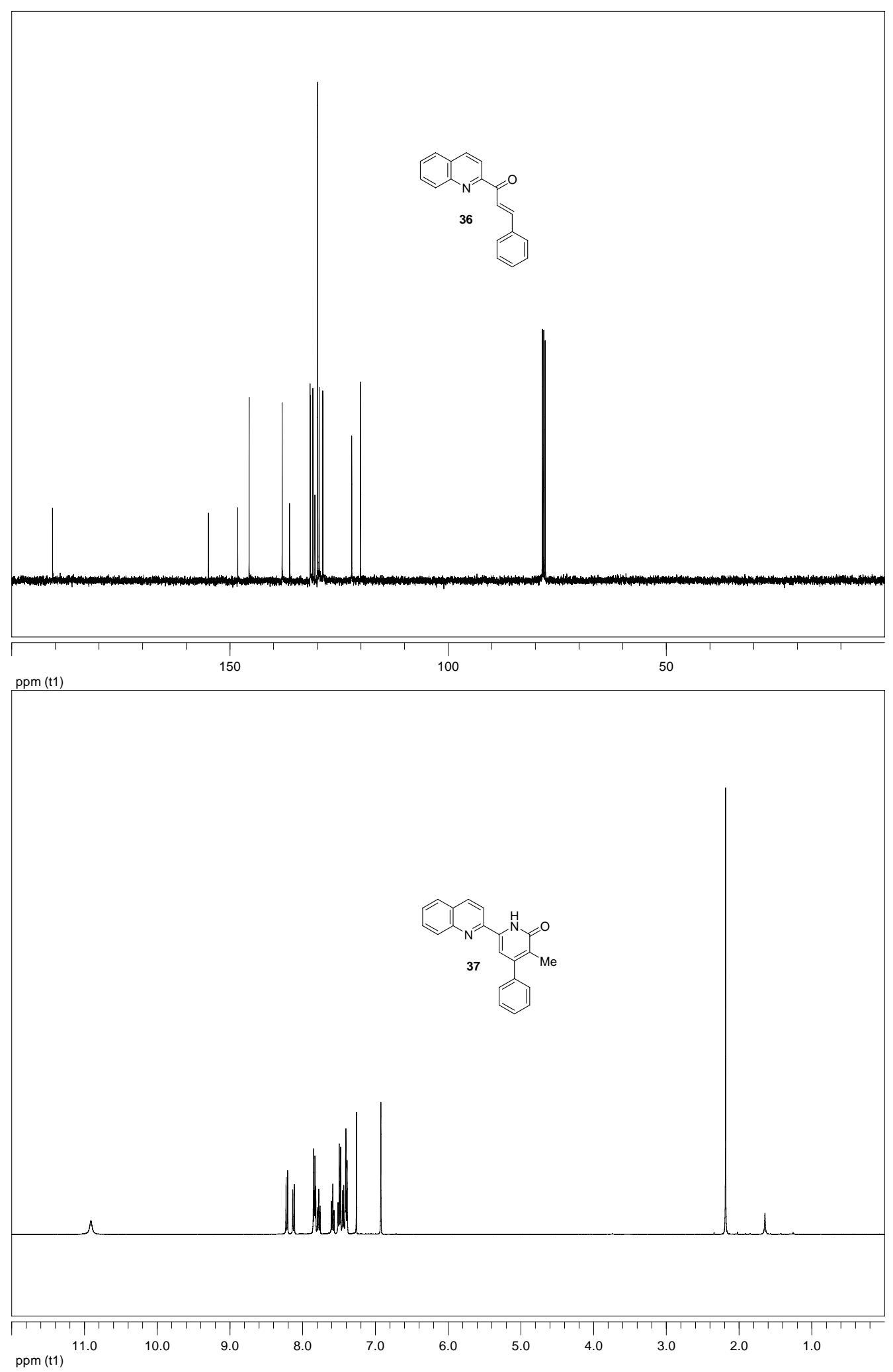

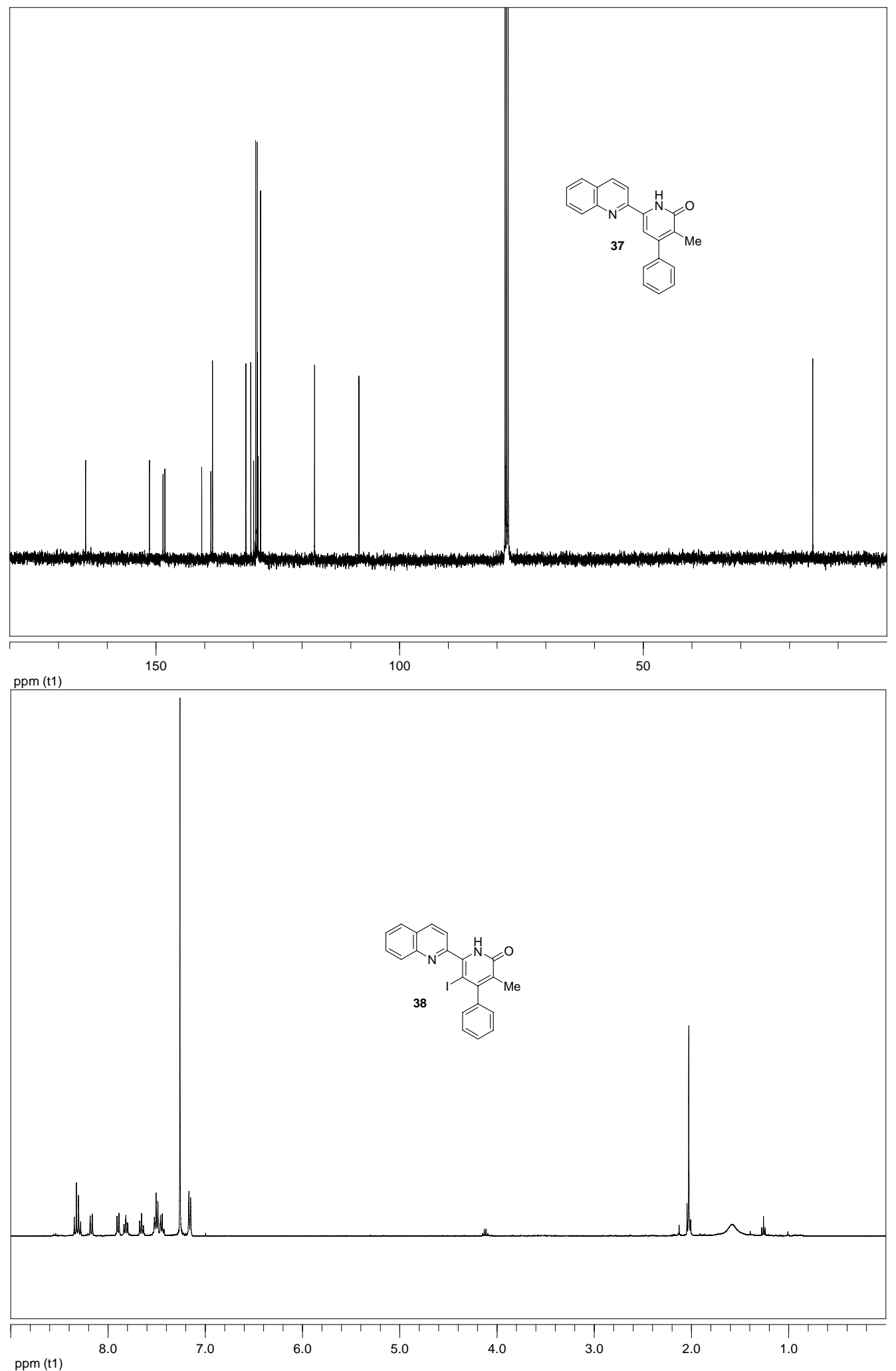


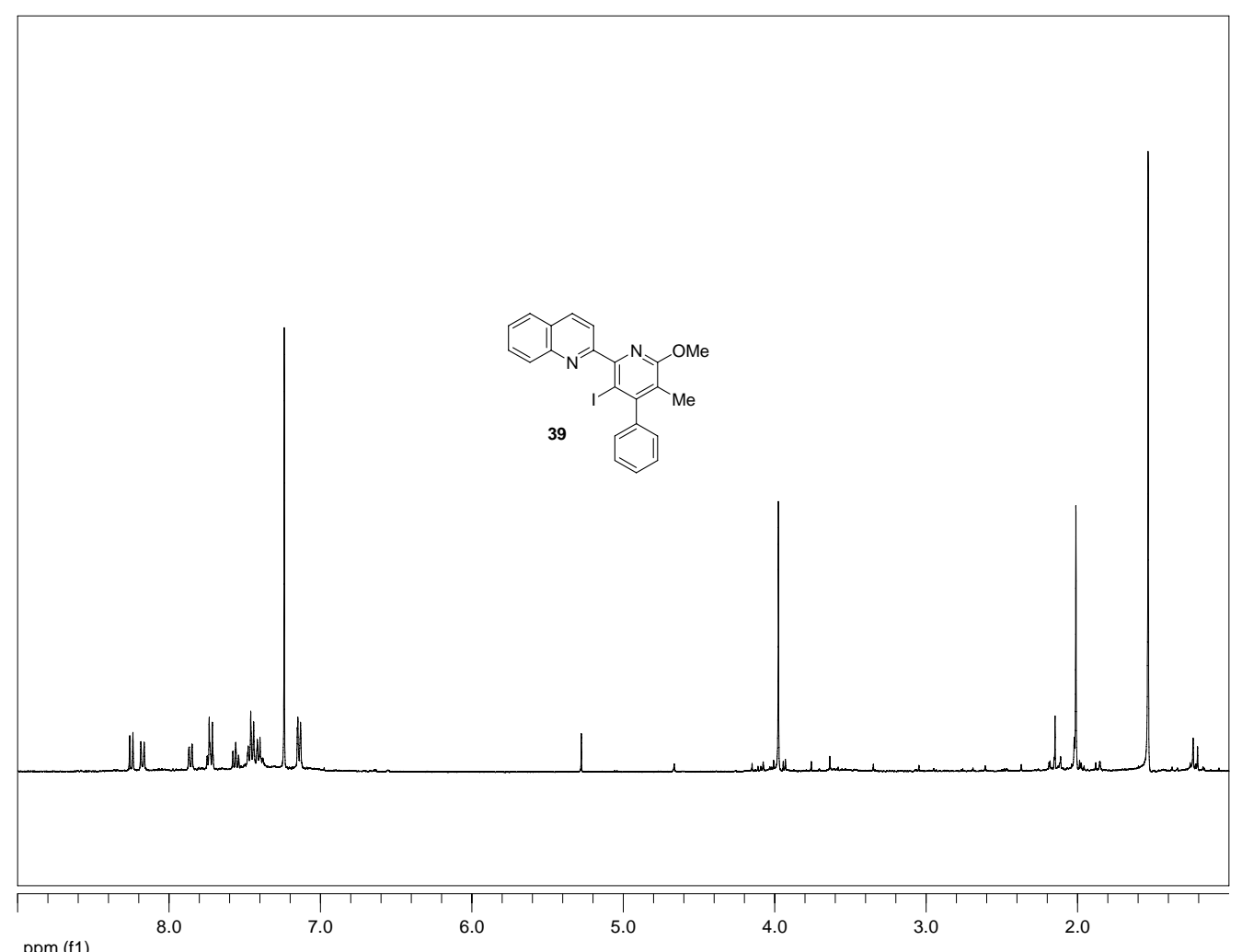

ppm (f1) 